\title{
SON ARAŞTIRMALAR IŞIĞINDA PERA SALON SERGILERI*
}

\author{
206 \\ THE PERA SALON EXHIBITIONS \\ IN THE LIGHT OF RECENT RESEARCHES*
}

Seza SINANLAR USLU**

\begin{abstract}
$\underline{0 ̈ Z}$
Pera'da gerçekleşen Salon Sergileri, Osmanlı resim tarihi içindeki en ilgi çekici etkinliklerden biridir. Paris'teki örneklerine benzer şekilde gerçekleştirilen Salon Sergileri sadece üç kez düzenlenmiş olmasına rağmen sanat tarihçileri tarafından Osmanlı resim tarihinde önemli bir nirengi noktası olarak görülmüştür. Son y1llarda derinleşen araştırmamızda faydalandığımız yeni kaynakların ışığında yeni tespitler ve yeni yorumlar yapma imkânı doğmuştur. Çalışma kapsamında Paris’te Bibliothèque Nationale başta olmak üzere, Paris Musée des Art Décoratifs Kütüphanesi, İstanbul Atatürk Kitaplığ Türk Tarih Kurumu Kütüphanesi ve İstanbul Üniversitesi Nadir Eserler Kütüphanesi'nde bulunan dönemin basın kaynakları, fotoğraf albümleri, sergi katalogları ile sergiler özelinde günlük olarak çıkan gazete haberleri ve eleştiri yazıları incelenmiş, elde edilen sonuçlar bu makalede paylaşılmıştır. Araştırmanın özgün kaynaklarından biri olan İstanbul Nadir Eserler Kütüphanesi koleksiyonunda bulunan Yıldız Fotoğraf Albümleri arasında 1902 ve 1903 sergisine ilişkin sergi mekânını ve eserleri gösteren fotoğraflar ise daha evvel hiçbir örnek eserine rastlamadığımız bazı sanatçıların sergideki eserlerinin görülmesine imkân vermiştir. Böylece bilinen bazı isimlerin görülmedik eserlerinin ortaya çıkarılması mümkün olmuş, söz konusu yapıtlar hakkında görsel veriye dayalı yeni değerlendirmeler yapılmasının da önü açılmıştır. Sonuç olarak Salon Sergilerinin daha bütünlüklü bir dizi etkinlik olarak görülmesi mümkün olmuştur.
\end{abstract}

Anahtar Kelimeler: Pera Salon Sergileri, Osmanlı resim sergileri, Régis Delbeuf, Celâl Esad Arseven, Yıldız Fotoğraf Albümleri

* Bu makale 16-18 Eylül 2015 tarihlerinde Napoli'de gerçekleştirilen 15. Uluslararası Türk Sanatları Kongresi'nde yazar tarafından sunulan ancak yayınlanmamış olan bildiriden geliştirilerek hazırlanmıştır.

* This article was developed from the unpublished paper presented at the 15th International Congress of Turkish Arts in Naples in 2015.

** Doç. Dr., Yıldız Teknik Üniversitesi, Sanat ve Tasarım Fakültesi, Sanat Yönetimi Abd., İstanbul. ORCID ID: https://orcid.org/0000-0003-0242-8062 • E-mail: sinanlar@yildiz.edu.tr 


\section{ABSTRACT}

The Salon Exhibitions that took place in Pera are among the most intriguing events in the history of Ottoman painting. Although these Salon Exhibitions, similar to their counterparts in Paris, were only held three times, they have been regarded by art historians as a critical reference point. Based on this significance, we have had the opportunity to make new interpretations in the light of new sources (from the Bibliothèque Nationale, Library of the Musée des Art Décoratifs in Paris, Istanbul Ataturk Library and Istanbul University Library of Rare Book,) we benefited from in our study.

At the first glance it should be said that we have used three different primary sources. These are the articles written in the daily newspapers of the time published in Istanbul such as Stamboul in French, Ikdam and Malumat in Ottoman, catalogues of these salon exhibitions (although the first one is missed), and the photo albums of Y1ldiz Palace, the most interesting one, which contain almost 40 photographs taken from the halls of 1902 and 1903 Salon exhibitions.

As the research method, it can be said that, first we brought together these sources and then matched the data to concrete information which was obtained about the exhibited works of some artists who participated in the 1902 and 1903 exhibitions. At this point it should be noted that Ikdam and Malumat were sometimes using visual materials whereas Stamboul did not. Therefore, we benefited from Stamboul's detailed descriptions in order to identify the paintings some of which are visible in Ikdam's and Malumat's pages at first. The data obtained from exhibition catalogues also helped us to clarify the names of artists and their artworks. In other words, extensive archival research and more effective use of press sources and also cross-reading of different media sources in the same period paved the way to obtain more comprehensive information about the Salon Exhibitions. Consequently, some artists whose works had not been discovered before were identified, and it became possible to make new evaluations regarding the content and style of these artworks based on visual data. As we are of the opinion that lack of visual materials prevent art historians from documentation of their work, we aimed at first to use visual materials as a big component and result of the research.

Finally, we should say that we tried to bring together new results as pieces of our documentation and experienced how it becomes possible to evaluate the skills of the artists through the images of their works many of which we cannot access today. We also found out how we should use different sources such as visual data, commentaries and archival documents all of which are based on individual stories and individual artistic activities that took place in Pera in Istanbul, the most cosmopolitan city of the Ottoman Empire in the $19^{\text {th }}$ century.

Keywords: Pera Salon Exhibitions, Ottoman exhibitions of painting, Régis Delbeuf, Celâl Esad Aresen, Ylldız Photo Albums 


\section{Giriş}

Osmanlı İstanbul'unda 19. Yüzyıl ortalarından itibaren münferit sanatçı atölyelerinde başlayan sanat eğitimi, önce Pierre Désiré Guillemet'in (1827-1878) eşi Hélène Guillemet ile birlikte açtı̆̆ Academie de Dessin et de Sculpture isimli özel akademide, sonra da Sanayi-i Nefise Mektebi çatısı altında yaygınlaşır. Bu sayede resim ve heykele duyulan ilgi artarken, bireysel ve karma sergilerin çoğalmasıyla plastik sanatlar daha fazla görünürlük kazanır. Bu sürecin ilk tepe noktası ise 20. Yüzyılın hemen başlarında karşımıza çıkan Salon Sergileri olmuştur denebilir. Paris’te Ecole de Beaux Arts ile beraber anılan Salon Sergileri'nin İstanbul'da da hayata geçirilmesi kuşkusuz 1800'lerin ikinci yarısından itibaren biriktirilen deneyimlerin doğal bir neticesidir. Yalnızca üç kez düzenlenmiş olmasına rağmen Pera Salon Sergileri ya da bazı kaynaklarda geçen adıyla İstanbul Salon Sergileri (bu metinde Pera Salon Sergileri deyişi kullanılacaktır) oldukça etkili olmuş gerek sergilerin düzenlenme biçimine, gerekse izleyici sürekliliğin oluşmasına katkı sağlamıştır. 1904'ten itibaren Singer Sergileri ${ }^{1}$ ile 1911'e kadar devam edecek Società Operaia Sergileri² bu devamlılığın parçaları olurken, Birinci Dünya Savaşı ve akabinde yaşanan işgal sürecine rağmen düzenlenen Galatasaray Sergileri ${ }^{3}$ ise resim tarihimizin en uzun soluklu sergileri olarak hayata geçmiştir. Pera Salon Sergileri bu açıdan bakıldığında 1901-1951 arasındaki 50 yıllık sergi pratiğinin ilk adımı olarak da anlam kazanmaktadır.

Son yıllarda yapılan kapsamlı arşiv araştırmaları ve basın kaynaklarının daha etkin olarak kullanılması ve aynı dönem içinde farklı basın kaynaklarının çapraz okumalarla değerlendirilmesi, Pera Salon Sergileri'ne dair daha kapsamlı bilgi edinilmesinin önünü açmıştır. Ne var ki bu çalışmalarda, sanat tarihi yazınının olmazsa olmazı görsel malzemenin diğer bir deyişle sergilerin esas konusu olan eserlere dair görsel bilgilerin yok denecek kadar az olması, yapılan değerlendirmelerin bu açıdan eksik kalmasına neden olmuştur. Şimdi ise yukarıda sayılan kaynaklara ilave olarak özellikle 1902 ve 1903 Salonu’na dair görsel malzemeye erişilmiş olmasının sağladığı imkanlar çerçevesinde, resim tarihimizin ilk kapsamlı etkinlikleri olan Pera Salon Sergileri hakkında yeni görüşler geliştirilmesi mümkün olmuştur.

Türk Tarih Kurumu Kütüphanesi’nde yeralan 1902 Sergisi kataloğu ile aynı sergi hakkında Stamboul gazetesi Régis Delbeuf'ün gazetede kaleme aldığı yazılardan oluşan sergi kitabının yanı sıra, İstanbul Üniversitesi Nadir Eserler Kütüphanesi’nde bulunan 1902 ve 1903 Salon Sergileri'ne ait fotoğraf albümlerine erişilmesi sonucunda söz konusu sergilere katılan sanatçılar ve teşhir edilen yapıtlar görsel malzeme desteğiyle çok daha somut bir zeminde değerlendirebilmiştir.

1 Singer Sergileri 1903 yılı Aralık ayından 1906 Temmuz ayına kadar dört defa gerçekleştirilmiştir.

2 Società Operaia Sergileri 1904-1911 yılları arasında beş defa düzenlenmiştir.

3 Galatasaray Sergileri 1916-1951 yılları arasında düzenli olarak gerçekleştirilmiş en uzun soluklu karma sergilerdir. 
Yıldız Albümleri olarak bilinen Sultan II. Abdülhamit döneminde hem saray dışından hem de doğrudan Yıldız Sarayı'nda görev alan fotoğrafçılar tarafindan çekilen fotoğraflardan oluşan bu albümler, günümüzde İstanbul Üniversitesi Nadir Eserler Kütüphanesi arşivinde korunmakta ve dijital kopyaları araştırmacılara açık tutulmaktadır. $\mathrm{Ne}$ var ki, albüm içeriklerini gösteren envanter kayıt etiketlerinin bazı albümler için çok az bilgi içermesinin bir sonucu olarak olsa gerek söz konusu sergilere ait albümler uzunca bir süre tespit edilememiştir. Birkaç yıl önce sanat tarihçisi Oğuz Erten'in kaleme aldığı bir yayında ${ }^{4}$ bu albümlerden bazı sayfalar paylaşılmış olması üzerine 90527 ve 90528 envanter numaralı Yıldız Albümleri incelenmiş ve bu fotoğrafların karma sergilere ait oldukları anlaşılmıştır. Ancak Erten'in ifade ettiği gibi bu albümlerin Pera Salon Sergileri'ne ait olup olmadığının teyit edilmesi için sergiler hakkında gazetelerde yer alan tanıtım ve eleştiri yazıları yeniden okunmuş ve katılan sanatçı ile eserler listelerindeki isim bilgilerinden hareketle 90527 envanter numaralı albümün içinde hem 1902, hem de 1903 tarihli Salon Sergisi'ne, 90528 envanter numaralı olanda ise sadece 1902 Salon Sergisine ait fotoğrafların yer aldığ1 tespit edilmiştir. ${ }^{5} \mathrm{Bu}$ aşamadan sonra da dönemin gazetelerinde yer alan haber vb. tür sergi yazıları, sergi kataloglar1 ${ }^{6}$ ve fotoğraf albümleri bir araya getirilerek eşleştirmeler yapılmış ve ağırlıklı olarak 1902 ve 1903 Sergileri'ne katılan kimi sanatçıların sergilenen eserleri hakkında somut bilgilere erişilmiştir.

Bu aşamada Osmanlıca kaynaklardan İkdam ve Malumat gazetelerinde zaman zaman görsel malzeme kullanıldığı için eserleri tanımanın daha kolay olduğunu, buna karşın Fransızca Stamboul gazetesinin görsel malzeme kullanmadığı için eserleri detaylı tasvirlerle anlattığını belirtmek gerekir. Böylece tasvir içeren yayınlar ile görsel malzeme kullanan yayınlar araştırmada birlikte değerlendirilmiş; birden fazla birincil kaynaktan gelen bu bilgiler hem çapraz okumalar hem de görsel karşılaştırmalar sonunda teyit edildikten sonra yeniden düzenlenerek makalede örneklenmiştir.

\section{Pera Salon Sergileri’nin ortaya çıkışı ve 1901 Salon Sergisi}

İstanbul'da bir salon sergisi yapma fikri kuşkusuz Şeker Ahmet Ali Paşa'nın düzenlediği 1873 Güzel Sanatlar Sergisiyle başlayan ve Sanayi-i Nefise Mektebi'nin açılmasının ardından her yıl düzenlenen yıl sonu sergilerinin sağladığı ivmenin bir sonucu olarak görülmelidir. Bilindiği gibi 19. Yüzyılın son çeyreği çeşitli grup sergilerinin yanı sıra Sanayi-i Nefise Mektebi (1883'ten itibaren) ve Guillemet Akademisi (1873-1882) yıl sonu sergileri ile Pera Caddesi (Grande rue de Péra) üzerindeki çeşitli dükkânların

4 Erten, 2012, c.1, 47-52.

5 İstanbul Nadir Eserler Kütüphanesi, Yıldız Sarayı Fotoğraf Albümleri, 90527 ve 90528 numaralı albümler.

6 Türk Tarih Kurumu Kütüphanesinde A/7812 envanter numarasıyla kayıtlı Deuxième Exposition des Artistes de Constantinople, Salon 1902, Catalogue ile aynı kütüphanede A.IV/0534 envanter numarasıyla kayıtlı Les Artistes de Constantinople, Salon de Pera, Deuxième Année, 1902.

7 Kaynaklarda yaygınlıkla Şeker Ahmet Paşa olarak yazılmasına rağmen Stamboul gazetesinde kullanılan Ahmet Ali Paşa tanımı bu makalede birleştirilerek Şeker Ahmet Ali Paşa olarak yazılmıştır. 
vitrinlerinde karşımıza çıkan bireysel sergilerin çoğaldığı bir dönemdir. ${ }^{8}$ Resim sanatına ilginin arttığı, eser alımlarının çoğaldığı, gazetelerde resim içerikli haber ve eleştiri yazılarının yaygınlaştı̆̆ı bu dönemde Pera'da Salon Sergisi açma fikri belirmiş, Sanayi-i Nefise Mektebi hocalarından mimar Alexandre Vallaury (1850-1921) ile Stamboul gazetesi editörü ve başyazarı Régis Delbeuf'ün (1854-1911) girişimleriyle çalışmalar başlatılmıştır. Böylece sergiye mekân bulunmasından, serginin duyurulmasına kadar birtakım çalışmalar öncelikli olarak bu ikili tarafından geliştirilmiş, serginin sekretaryasını yine Sanayi-i Nefise Mektebi'nden Joseph Warnia Zarzecki (1850-?) üstlenmiştir. Şimdiye kadar pek çok kaynakta ifade edildiği gibi 1901'deki ilk Salon Sergisi, Pera Caddesi üzerindeki Pasaj Oryantal (Şark Aynalı Pasajı) içindeki Bourdon Evi’nde yapılmıştır. Ancak hiç sorulmayan sorulardan biri mekân tahsisinin nasıl sağlandığı konusudur. Bay Bourdon kimdir? Neden evini böyle bir sergiye açmıştır? Ya da kimler Bourdon Evi’nin sergi mekânı olması konusunda çaba sarf etmişlerdir? Bu soruların cevabı, Stamboul gazetesi yazarlarından ressam ve öğretmen Prétextat Lecomte ${ }^{9}$ (1857-1938) tarafindan verilmiştir. Lecomte, sergi mekânı olarak Bourdon Pastanesi'nden söz ederken sergi için Bourdon Evi'nin yanı sıra bir de alttaki pastanenin de kullanıldığını yazarak önemli bir detay iletmiş olur. ${ }^{10}$ Böylece sözü edilen pastanenin Pasaj Oryantal girişinde bulunan eskiden Lebon, sonraki yıllarda Markiz olarak tanınan pastane olduğunu anlaşılır. Nitekim Celâl Esad Arseven de İkdam gazetesindeki yazısında serginin, Lebon Pastanesi'nin üstündeki daireyi de içine alarak iki salona dağıtıldığını söylemiştir. ${ }^{11}$ Üst kattaki daire Charles Bourdon'a ait Bourdon Evi, alttaki dükkân ise Bourdon et Lebon Pastanesi'dir. Edinilen bilgiye göre Charles Bourdon ve Eduard Lebon ortaklaşa Bourdon et Lebon adiyla bir pastane kurmuşlar, babası pastacı olan Alexandre Vallaury de pastanenin dekorasyonunu yapmıştır. Bu tanışıklığın devamında Vallaury'nin kız kardeşi Hélène Vallaury, Edouard Lebon ile evlenmiş, böylece taraflar arasındaki ilişki akrabalığa dönüşmüştür. Bu ilişkinin sağladığı kolaylaştırıcılıkla da Vallaury ile Delbeuf'ün düzenlemek istedikleri Salon Sergisi için, Vallaury'nin kayınbiraderi olan Edouard Lebon'un pastanesi ile ortağının aynı pasajdaki evinin kullanılmasına karar verilmiş olmalıdır. Sergi açıldığında Bourdon Evi'nde yaşam olup olmadığı ise henüz bilinmemekle beraber, Bay Bourdon'un evinde daimî bir ikametin olmadığını, dairenin boş olduğunu düşünmek daha makuldür. Mekân için kira bedeli ödenmediği için ilk serginin ücretsiz olduğu ${ }^{12}$ hesaba katılırsa, kişiler arasındaki yakın ilişkiler üzerine bu iş birliğinin temellendiği düşünülebilir.

Sergi mekânı kesinleştikten sonra 1901 yılının 13 Mayıs Pazartesi günü ilk Salon Sergisi açılır ve 25 sanatçıya ait 170 kadar eser izleyiciye sunulur. Büyük ilgi çeken sergi hakkında Stamboul gazetesinde Régis Delbeuf'ün, İkdam'da ise Celâl Esad'ın yazıları gün gün devam eder.

8 Sinanlar, 2008, 48-53.

9 Sinanlar, 2009, 59-67.

10 Stamboul, 13 May1s 1901.

11 Celal bin Esad, Resim sergisini ziyaret, Íkdam 21 Mayıs 1901'den akt.: Öziyiğit, 2012, 164-166.

12 Stamboul, 13 Mayıs 1901. 
Delbeuf'ün yazılarında genelde aynı başlık altında her bir sanatçı için önce kısa biyografik bilgiler sunduğu devamında da sanatçılar özelinde üslup ve tekniklerine yer verdiği görülür. Hangi sanatçının, kaç eserle sergiye katıldığı, nerede yaşadığı, eğitimini nerede ya da kimden aldığı, benimsediği üslubu, resimlerinin konusuna dair yazılanlara bakılırsa Delbeuf, serginin kataloğundan bu bilgileri derlemiş olmalıdır. Söz konusu yazılar günümüzde yeniden okunduğunda o tarihlerde henüz tanımlı bir eleştirmen sıfatı taşımasa da Delbeuf'ün eleştirel bir gözle yaklaştığı söylenebilir. Benzer durum Celâl Esad'ın yazıları için de geçerlidir. Celâl Esad da yazılarında mutlak surette kendi görüşlerini ve yargılarını olanca samimiyetiyle okurlara sunmuştur.

Bugün hâlâ 1901 Pera Salon Sergisi’nin kataloğuna ulaşılmamıştır. Ancak serginin düzenleyicilerinden olan Delbeuf'ün yazısından eser kataloğundan yararlandığı anlaşılmaktadır. Tam bir alfabetik sıralama takip etmeden verilen isimler 1'den 24'e kadar şu şekilde sıralanmıştır: Ahmet Ali Paşa, Adil Bey, D’Aranda Paşa, Adolphe Beaume, Philippo Bello, Chahin (Şahin), George Cain, Bay ve Bayan Delavallée, Emilio Dellasuda, J. Fabrizi, Stephano Farnetti, Thalia Floras, De Forcade, Lina Gabuzzi, Halil Paşa, Osman Hamdi Bey, Leonardo de Mango, Osgan Efendi, Prieur Bardin, Schiffi, Seldjobalof, Salvatore Valeri, Warnia Zarzecki ve Fausto Zonaro ${ }^{13}$. Katılımcı sayısının 25 olduğu ifade edilmekle beraber muhtemelen katalogda Delavallée çifti tek bir numara altında verilmiş olduğu için Delbeuf'ün listesinde toplam katılımcı sayısı 24 olarak ifade edilmiştir.

1901 sergisinin içeriğine bakıldığında sergideki en etkili çalışmaların peyzajlar olduğu konusunda Delbeuf ve Celâl Esad'ın aynı fikirde olduğu görülür. Ancak kişisel olarak Celâl Esad'ın yazdıklarından en çok Thalia Floras'ın portrelerini beğendiği söylenebilir. ${ }^{14}$

Celâl Esad'ın dikkat çektiği bir diğer eser ise Şeker Ahmet Ali Paşa'nın Bir Vaftiz Merasimi isimli eseridir. Yazar bu tabloyu "sanatçının yeteneklerini üzerinde toplayan bir eser" olarak gördüğünü ifade etmiştir. ${ }^{15}$ Söz konusu eserin adından yola çıkarak bu tablonun natürmort olmadığını sezmek mümkün olsa da eserin figür içeren bir sahne olup olmadığı konusunda herhangi bir yoruma rastlanmaz. Delbeuf, Şeker Ahmet Ali Paşa'nın biri natürmort iki peyzaj ile katıldığını söylemekle yetinir. Bu da akıllara yeni bir soru getirir: Bir Vaftiz Merasimi isimli Şeker Ahmet Ali Paşa tablosu acaba bugün bir yerlerde mevcut mudur? Araştırma sürecinde karşılaşılmamış olsa da bu isimde bir eserin günün birinde ortaya çıkabileceği ihtimali dikkate değerdir.

Sergideki eserler hakkında her iki yazarın fikir birliğinde olduğu görülür. Sanatçılar ağırlıklı olarak manzara tablolarıyla katılmışlar ve eserlerinde de çoğunlukla Boğaz, Üsküdar ve Haliç bölgesini konu almışlardır. Bu tarz resimler arasında en çok Leonardo de Mango'nun resimleri ilgi görürken, teknik açıdan ise sergide daha çok

13 Stamboul 29 May1s, 30 May1s, 31 May1s, 12 Haziran, 15 Haziran 1901.

14 Özyiğit, 2012, 167-169.

15 Özyiğit, 2012, 167. 
yağlı boya etkin olmasına rağmen Philippo Bello suluboyalarıyla, Bayan Delavallée de pastelleriyle dikkat çekmiş, Lina Gabuzzi gravürleri, Matmazel Fabrizi ise vitraylarıyla beğeni toplamıştır. ${ }^{16}$ Natürmortlar arasında ise Şeker Ahmet Ali Paşa ile Bayan Seldjobalof'un öne çıkarıldığı görülmüştür.

Delbeuf'ün aktardığına göre Pera'daki ilk Salon Sergisi, “İstanbul'da sanattan anlayan bir izleyici kitlesinin olmadığı" yargısının kesin bir şekilde reddedilmesine olanak veren bir sergidir. ${ }^{17}$ Nitekim sergi daha ilk günden büyük bir ilgi görmüş, hatta ilk hafta içinde satılan resimler yerlerinden indirildiği için serginin son günlerinde salon neredeyse tamamen boşalmıştır. ${ }^{18} \mathrm{Bu}$ durum sergi kurallarının uygulanması konusunda bir tecrübesizlik yaşandığını düşündürse de izleyicilerin resim satın alma arzusunu ortaya koyması bakımından önemlidir. Biraz da ilk serginin heyecanıyla olsa gerek, alım gücü olan sanatseverlerden Bay Zarifi, Fransız elçi Constans ve eşi, Komutan Berger, Bay Bapst gibi isimler ilk alıcılar olurken, Düzenleme Komitesi başkanı sıfatıyla Alexandre Vallaury ile Sanayi-i Nefise Mektebi hocalarından Salvatore Valeri gibi isimler de "sanatçı alıcılar" olarak satışlara destek olmuşlardır. Bu kişilerden başka, ön isimleri zikredilmeyen paşa ya da memur konumunda olan birtakım kişilerin de eser satın aldıkları belirtilmiştir. ${ }^{19}$ Serginin son günlerinde salonun boşaldığına bakılırsa eserlerin çoğu satılmış ve satın alınan yapıtlar sergi salonundan çıkıp, kişilerin evlerine girmiştir. $\mathrm{Bu}$ açıdan bakıldığında 1873 'te başlayan sergilerin Osmanlı toplumu içinde plastik sanatlarla ilişkilenen bir grubun oluşmasına her geçen gün katkı sağladığı ve ilk salon sergisinde de görünürlük kazandı̆̆ söylenebilir.

Sergide yer alan sanatçılar etnik kökenleri bakımından incelendiğinde ise o günün Osmanlı dünyasındaki tüm etnik unsurları görmek mümkündür. Öyle ki Müslüman, yerel Gayrimüslim, Levanten ve Avrupa'lı olmak üzere dört farklı kimlikte, 5'i kadın toplam 25 sanatçı Pera'daki kozmopolit yaşamı da temsil ederek bir araya gelmişlerdir. Delbeuf'ün aktardığına göre Fransız Elçi Constans ve Bay Bapst'a bakılırsa ortaya çıkan sergi yalnızca bir defa ziyaretle tam olarak idrak edilemeyecek kadar zengin bir sergidir; tekrar tekrar gidilmesi ve görülmesi gereken eserlerle doludur. ${ }^{20}$

Sergideki sanatçılar içinde en çok dikkat çeken isimlere bakıldığında hiç kuşkusuz Avrupa resim tarihinden de isimlerini bildiğimiz Henri Delavallée ve eşi Gabrille Moreau Delavallée'ye ayrı bir ilgi gösterildiği söylenmelidir. Çift muhtemelen sergi tarihinden daha önce İstanbul'a gelmiş ve bir süredir burada yaşıyor olmalıdır. Nitekim senaryosunu araştırmacı ve sinema tarihçisi Saadet Özen'in kaleme aldığı Bırak Çocuk Oynasın isimli uzun metrajlı dokümanterde Henri Delavallée'nin İstanbul'da Sponek Birahanesi'nde gösterilen kısa filmleri temin eden kişi olarak eşiyle beraber

16 Özyiğit, 2012, 167-169.

17 Stamboul, 16 May1s 1901.

18 Stamboul, 17 May1s 1901.

19 Stamboul, 18 May1s 1901.

20 Stamboul, 16 Mayis 1901. 
1896-97 yıllarında İstanbul'a gelmiş olduğundan bahsedilmektedir. ${ }^{21}$ Çiftin resimleri ise Delbeuf'e göre hayli ilgi çekicidir. Delbeuf renk unsurunun çok etkin olduğunu söylediği tabloları şu sözlerle tanımlar:

(Henri Delavallée'ye hitaben) İtiraf ediyorum ki, ilk ziyaretimde biraz karışıklık hissetmiştim. Bu çok kişisel vizyon ve renkler benim için konsantrasyon bozucuydu. Vallaury büyük bir şevkle bu tarz bir yorumu savunuyordu. İkinci kez gördüğümde ise alıştığımı söylemeliyim. Artık doğu güneşinin bu şekilde gösterilmesini yadırgamıyorum. Ancak bu durumu diğer peyzajistler nezdinde 1 şı problemi olarak daha görüşeceğiz." (...)

(Madam Delavallée'ye hitaben) Herkes ilk bakışta anlamayabilir resimlerinizi mesela Büyükdere peyzajınızdaki Kafkasyalı kadının elbisesini çok sarı, Gambetta Oteli'nin ağaçlarını da çok yeşil bulabilir. Ama önümüzdeki sene buna alışmış olacaklardır. Şimdi onları şok eden bu renkler seneye bir armoni duygusu verecektir. ${ }^{22}$

$\mathrm{Bu}$ sözlerle Delbeuf'ün başta yadırgadığı ancak sonra alıştığını söylediği çok renkli çalışmalar, 1905 yılında Louis Wauxcelle'in Sonbahar Salonu'nda gördüğü eserleri anlatırken kullanacağ fauves / vahşiler ${ }^{23}$ tabirinden hareketle türetilmiş Fovizm (fauvism) akımının erken örnekleridir aslında. Ne var ki, henüz sanat tarihinde Fovizm tanımlanmamış olduğu için Delbeuf, bu akıma örnek tabloları "çok sarı" ya da "çok yeşil" şeklinde ifade ederek farkında olmadan Fovizm akımına dahil olacak bu erken örnekleri ayırt etmeye çalışmıştır. Aynı tablolar için Celâl Esad da, Delavallée'yi öne çıkararak sanatçının empresyonist tavırla yaklaştığı tablolarında parlak renkleri yakaladığından bahsetmiştir. $^{24}$

Eserleri tanıtan bu yazılar arasında zaman zaman memnuniyetsizlikler de dile getirilmiştir. Özellikle Delbeuf, Ömer Adil Bey’in (Delbeuf, Adil Bey adını kullanır) resimleriyle ilgili olarak sanatçıyı kendi özünden kopmuş olarak tanımlarken kendi kişisel resim beğenisini öne çıkararak sevdiği tarzın bir yerde oryantalist konular olduğunu ifade eder ve şunları dile getirir:

Konstantinopolis'te doğmuş ve onu unutmuş bir başka sanatçı. Gönderdiği 7 tuvalden yalnızca biri doğu konulu ve o da en iyisi değil üstelik. Kalanlar çoğunlukla İtalya esintisi taşıyor. Tanrı elbette İtalyan semaları hakkında kötü konuşmamızı yasaklamıştır ama bu denli tekrar edilmiş olması da... (...) Ancak Adil Bey, İtalya'dayken kendi anavatanından birkaç sahne saklayabilseydi gözlerinde biz daha tatmin olacaktık. Büyük usta Fransız heykeltıraş Denys Puech, Paris’i Roma’ya

21 Bırak Çocuk Oynasın, Yapım yılı 2018, Yönetmen: Hacı Mehmet Duranoğlu, Atalay Taşdiken

22 Stamboul, 22 May1s 1901; Sinanlar, 2008, 248.

23 Antmen, 2008, 36.

24 Özyiğit, 2012, 169. 
gitmek üzere terk ettikten sonra gönderdiği ilk eseri Tiber ırmağından mı esinlenilmiştir zannediyorsunuz? Hayır! Paris'i kutsayan bir eserdir. Seine nehrinden harika bir su perisiydi o eser. Bu anayurdun, doğduğu toprağın bir nostaljisiydi. Fransa'dan İtalya'ya giden sanatçıya ilk ilham veren şeydi bu! Buna benzer bir davranışı Adil Bey’de de görmek isterdik. Onu değerlendirmek için doğunun saf kaynaklarına, doğduğu yere ilişkin şeyler yapmasını bekliyoruz. ${ }^{25}$

Pera'da gerçekleştirilen bu ilk serginin heyecanını yürekten hisseden bir başka isim ise Paris'te bulunan Adolphe Thalasso'dur. ${ }^{26}$ Serginin ilk günlerinden itibaren Delbeuf ile yazışarak sergi hakkındaki görüşlerini dile getiren Thalasso, 24 Mayıs 1901 tarihli mektubunda İstanbul'lu sanatçıların Paris'te tanıtılması gerektiğine inanarak bu konuda yapılması gerekenleri şöyle dile getirir:

Büyük bir sevinçle Pera'nın artık bir Salon Sergisine sahip olduğunu öğrendim. İstanbul'da doğmuş ve onu sanatsal bir kariyer uğruna terk etmiş biri olarak bu şehirde yaşanan hiçbir sanat olayına kayıtsız kalmam mümkün olamaz. (...) Sergi hakkında kapsamlı bir etüt yazısı hazırlayarak, bir yerde doğu hakkında, Türk Tiyatrosu, Müze-i Hümayun'a dair yazdıklarımın ardını getirmek istiyorum. Coşku dolu yazılarınızdan sonra düşündüm de, bizim Levanten sanatçılarımızı isimleri ve eserleriyle Fransa'da tanıtmalıyız. Bu düşünce ile tüm sanatçılara bir çağrıda bulunmak istiyorum. Olabildiğince kısa süre içinde tablolarının, heykellerinin ve gravürlerinin fotoğrafları ile biyografik bilgilerini sanatın yeni merkezi İstanbul'dan bana göndersinler. ${ }^{27}$

Thalasso'nun hayli coşkuyla dile getirdiği teklifi ne yazık ki, İstanbul'daki sanatçılar nezdinde pek karşılık görmez. Sergi kapandıktan bir süre sonra Delbeuf, Thalasso'nun mektubunu hatırlatarak kimsenin fotoğraf ya da biyografi getirmediğini yazar. ${ }^{28}$

Sergide eser satışına geri dönülecek olursa, konuyla ilgili olarak Delbeuf'ün satılan eserlerin fiyatlarına dair söyledikleri dikkat çeker. Şimdiye kadar üzerinde pek durulmamış olan bu konuda Delbeuf, Valeri'nin çok beğenilmesine rağmen fiyatı nedeniyle alıcı bulamayan tablosundan bahsederken şunları yazar:

Ve pek çok kişi sanatçının (Valeri'den bahsediliyor) yaptığı bu çigan başlarından birini almak istedi. Girişte yeralan bu kadın başları gerçekten dikkat çekici. Ama ne yazık ki, henüz İstanbul halkı bir sanat eseri almak için büyük özverilerde bulunmaya alışmış değil. Eğer bu tür sergiler

25 Stamboul, 17 May1s 1901.

26 Thalasso 1857 yılında İstanbul'da dünyaya gelmiş, yayıncılık alanında çalışmalar yaptıktan sonra 1888 yılında Paris'e yerleşir ve hayatının sonuna kadar burada kalır. Sinanlar Uslu, 2014, 261-272.

27 Stamboul, 29 Mayis 1901.

28 Stamboul, 28 Haziran 1901. 
her yıl olmaya devam ederse bu alışkanlık kazanılabilir. Eserlerin fiyatlandırılması da çok hassas bir konu. Ancak bir sanatçı, eserinin fiyatını söyleyebilir. Burası pazar değil, burada patates alınmıyor. Bize öyle geliyor ki sanatçılar da alıcıların, onların yaşamakta oldukları ortamı hem psikolojik hem de maddi açıdan bilsinler istiyorlar.

Örneğin Paris’te sanat eserleri ulaşılabilir fiyatlardadır. 1000, 2000 ve 3000 franka tuval satın alınabilir. Hem de tanınmış isimlere ait eserlerden bahsediyoruz.

Biz buradaki sergide önceki gün iki kadının arasında geçen şu konuşmayı duyduk:

"Sordun mu kaçaymış?"

"50 lira

"EEE?

"Eesi , bu fiyata 2 halı almayı tercih ederim, hiç olmazsa daha çok işe yarar!

Bu kadın için bir halı kesinlikle bir tablodan daha değerli. Hatta belki bir havagazı ocağı almak bile daha akıllıca. Ama o kadının sanat eserleri üzerine fikir beyan etmeye hakkı yok! Sanatçılar, eserin gerçek sahibidirler ve yalnızca onlar eserin değerini fiyatlandırabilirler. Valeri gibi bir adam, bizim sözümüzü anlıyor ve biçtiği fiyatın haklılığını biliyordur. $^{29}$

Delbeuf'ün vurguladığı gibi sanat yapıtı üretmek, sergilemek ve sonrasında eseri satabilmek toplum açısından bakıldığında sanata ilgi duyma, sanatsever olma ve sanatın alıcısı olma süreçlerinin gelişmesiyle doğrudan ilişkilidir. Dolayısıyla 1883 yılından itibaren devlet eliyle kurulan Sanayi-i Nefise Mektebi'nin estirdiği havanın, 1900'lere gelindiğinde ancak kalabalık karma sergileri gündeme taşıyabildiğini söylemek gerekir. Henüz sanat üzerinden kurulan bu yeni ilişki ile toplumun sanatsever olması ve akabinde sanat alıcısı olabilmesi için daha çok zaman geçmesi gerekecektir.

\section{Pera Salon Sergisi}

İkinci Pera Salon Sergisi'nin hazırlıkları gazetelere bakarsak açılıştan aylar önce başlamış, hatta ilk haber 9 Aralık 1901 tarihinde Stamboul gazetesinde yayımlanmıştır. Ertesi gün de neredeyse aynı haber İkdam'da tekrarlanmıştır. ${ }^{30}$ Her iki haber içeriğinin benzerliğine bakılırsa, sergiye dair bir basın bülteninin gazetelerle paylaşılmış olabileceğini iddia etmek mümkündür. Bu iki haberde de 1902 Sergisi'nin, 15 Nisan - 31 Mayıs tarihleri arasında gerçekleştirileceği duyurulmakta, sergi hakkında bilgi almak isteyenlerinse her cuma sabah 10'dan öğlene kadar Taksim Meydan1 9 numarada bulunacak olan Philippo Bello'ya danışabilecekleri belirtilmektedir. Haberden yola çıkarak organizasyo-

29 Stamboul, 12 Haziran 1901.

30 Stamboul, 9 Aralık 1901; Özyiğit, 2012, 169. 
nun gayet programlı başladığı söylenebilir. Zira komite bir nizamname hazırlayarak, sergi yönetmeliğini basına servis etmiştir. 4 Nisan 1902 tarihinde Stamboul gazetesinde yayımlanan bu yönetmelikte sergi kuralları duyurulmuştur. Haberin içeriğinde serginin Pera Caddesi üzerinde 417 numarada açılacağı bilgisi de paylaşılmıştır. O günkü 417 numara Abdullah Biraderler'in eski stüdyosunun da bulunduğu Friedman Apartmanı'dır. Bugün de ayakta olan binada yakın zamana kadar Galeri Arter bulunmuş, şimdilerde ise Galeri Meşher yer almaktadır. Söz konusu mekânda sergi faaliyetlerinin devam ediyor olması, Pera'dan Beyoğlu'na tarih içinde aktarılan güzel bir devamlılık olarak yorumlanabilir.

Yukarıda bahsi geçen nizamnameye dönülürse Düzenleme Komitesi'nin ilk sergiden edinilen bazı tecrübeler ışığında hareket ettiği söylenebilir. Bahsi geçen yönetmelik açılış tarihinden 10 gün kadar önce gazetelerde yayımlanarak duyurulmuş ve aşağıdaki şekilde maddelenmiştir:

1. İstanbul'da 15 Nisan- 31 Mayıs 1902 arasında resim, mimarlık, heykel, mozaik, gravür ve desen sergisi açllacaktır.

2. Sergi, Türkiye'de otursun ya da oturmasın tüm ülkelerden sanatçılara açık olacaktır.

3. Eserler en geç 5 Nisan'da çerçeveli olarak teslim edilecektir.

4. Sergiye katılan her sanatçı, eserin altına kendi adını soyadını, imzasını, doğum yerini, adresini ve eserin boyutlarını yazacaktır.

5. Her katılımcı, eserlerini sergi boyunca satabilir. Ancak satışın \%10’u sergiyi yapanlara birakılacaktır.

6. Düzenleme komitesi eserlerin korunması için elinden geleni yapacaktır.

7. Sergiyi düzenleyenler arasından seçilecek jüri tarafından eserlerin ne şekilde yerleştirileceği kararlaştırılacaktır.

8. Sergilenen eserlerin orijinal olması gerekmektedir. Kopyalar kabul edilmeyecektir.

9. Eserler kapanışın ertesi günü, yani 1 Haziran 1902 günü, komite sekretaryasının gözetiminde sahiplerine teslim edilecektir.

10. Sergi süresinde hiçbir eser sergiden çekilemez.

11. Sergiye katılan sanatçı sabit bir fiyatla alacağı bir kartla kendi misafirlerini ücretsiz olarak sergiye sokabilecektir. (Şunu da eklemeliyiz ki, söz konusu kart üzerinde meşhur bir ressamımızın çizdiği İstanbul panoraması önünde doğulu Rum bir kadın görünüyor.)”31

Yukarıda yer alan yönetmelikte en çok dikkati çeken konulardan ilki satılan eserlerin sergi kapandıktan sonra alıcıya teslim edileceği hususudur. Zira ilk sergide

31 Stamboul, 4 Nisan 1902. (Bahsedilen meşhur ressam Fausto Zonaro'dur. Çizim sergi tanıtım görseli olarak kullanılmıştır.) 
bu konuda bir karar alınmadığı için ödemeler yapılır yapılmaz alıcılar eserleri alıp götürmüşler, bu yüzden eser satıldıkça sergi mekânı boşalmış, bu haliyle serginin bir tür pazara benzediği yönünde eleştiriler yapılmıştır.

Yönetmelikte belirtildiğine göre sanatçılar misafirlerini sergiye ücretsiz olarak sokabilecekleri bir kart satın alacaklardır. Sergi hem yerel sanatçılara hem de uluslararası sanatçılara açık olurken, İstanbul'da ikamet etmeyen, Osmanlı tebaasına dahil olmayan Avrupa'lı sanatçıların da sergiye katılmaları bir önceki sergide olduğu bu sergide de mümkün olacaktır. Bir diğer konu ise eserlerin yerleştirilmesiyle ilgilidir. Buna göre eserlerin ne şekilde asılacağına komite üyeleri karar verecektir.

Sergiye dair hazırlanan bu yönetmeliğin doğrudan bir katkısı olmuş mudur bilinmez ama ilk sergiye göre katılımcı sayısı 25'ten 36'ya çıkmış, eser sayısı da ilkine göre neredeyse iki katı oranla 170’ten 330'a ulaşmıştır. İlk sergiye 5 kadın 31 eserle katılmışken, ikinci sergiye 11 kadın 65 eserle katılmışlardır. En çok eser verenler ise 33 yapıtla Leonardo de Mango, 30 yapitla Zonaro, 23 eserle Halil Paşa ve 22'şer eserle Lina Gabuzzi ile Thalia Floras olmuştur. Kadınların hem katılımcı sayısı hem de eser sayısıyla sergide etkili oldukları anlaşılmaktadır. İzleyici açısından bakıldı̆̆ında ise, ikinci serginin ilk on günde yaklaşık 5bin kişi tarafından gezildiği görülmektedir. ${ }^{32} \mathrm{Bu}$ rakamsal verileri gazetede paylaşan Delbeuf bilet satışları üzerinden yaptığı hesabı şöyle aktarır:

Girişin ücretsiz olduğu ilk günde sergiyi 130 kişi ziyaret etti. Ertesi gün 325 , sonraki gün 385 ve tatil olan Cuma günü ise 863 ziyaretçi sergiye geldi. Rakamlar toplandığında ilk 4 günde 1703 kişinin sergiyi görmüş olduğu ortaya çıkar. Cumartesi ve Pazar günü ise 1093 kişi daha geldi ve sergi ilk haftasında 2796 kişiye ulaştı. Cuma günleri her zaman daha çok ziyaretçi geliyor (mesela 18 Nisan 1902 günü 863, 25 Nisan 1902 günü de 1208 kişi) ve işte bu Cuma da sergiyi 1200 kişiden fazla gezen oldu. Türkler bu serginin önemini çok çabuk kavradılar. Çok ulusal bir duyguyla, onurla geliyorlar. Sanayi-i Nefise'nin Müslüman öğrencileri bu sergide çok parlak bir yer tutuyorlar böylelikle de Pera Salonlarının geleceği garantilenmiş oluyor. ${ }^{33}$

Delbeuf'ün rakamlarını günümüzde İstiklal Caddesi üzerindeki çeşitli sergi mekanlarının günlük ziyaretçi sayılarıyla karşılaştırıldığında sözlü olarak edinilen bilgilere göre ${ }^{34}$ ücretsiz girilen mekanlarda ortalama olarak hafta içi günlük ziyaretçi sayısı görüş alınan her bir mekân için takribi 150-200 civarında, hafta sonları ise bu rakam 500-700 civarında seyretmektedir. Verilen bu bilgiler ışığında günümüzdeki rakamların şaşırtıcı bir şekilde 1902 Sergisi’nin rakamlarının bir hayli altında kaldığı görülmektedir.

32 Stamboul, 4 Nisan 1902.

33 Stamboul, 21, 26 Nisan 1902.

34 Ziyaretçi sayıları ortalaması İstiklal Caddesi üzerinde Akbank Sanat, Yapı Kredi Kültür Merkezi ve Salt Beyoğlu galerilerinin güvenlik birimlerinden kişilerle pandemi öncesinde yapılan sözlü görüşmelerden edinilmiştir. 
Sergiyle ilgili yapılan bir başka düzenleme ise Saray kanadından gelmiştir. Saray yani Sultan II. Abdülhamit Düzenleme Komitesi'nin hazırladığı yönetmelikte belirtilmemiş olmasına rağmen sergide nü resimlerin olmamasını talep etmiştir. ${ }^{35}$ Delbeuf de konuyu şu şekilde değerlendirmiştir:

Sergide "Nü de mi yok?" diyebilirsiniz. Doğru. Sanatsal ve de ahlaki açıdan pek çok sebep nedeniyle nü yok. Henüz halk yeni yeni bu tür sergilere alışıyorken, kimseyi ürkütmemek gerek. Pera Salonu, kızıyla gelen bir anneyi, ya da geldikleri bağnaz çevrenin etkisi hâlâ üzerinde bir kadının ahlaki sorular sebebiyle sergiden kaçmasına neden olmamalı. ${ }^{36}$

Delbeuf'ün açıklamasına bakılırsa, sergilerde halk açısından daha doğrusu doğrudan kadın izleyiciler açısından gözetilmesi gereken en önemli husus tablolarda çıplak figür olmaması ve bu içerikteki resimler nedeniyle sergiye gelen kadınların rahatsızlık hissetmemeleridir. Bu yaklaşımda en çarpıcı vurgu hiç kuşku yoktur ki kadın izleyicilerin sayısının azalmaması vurgusudur.

Eleştirilere gelince, Delbeuf'ün ilk sergide olduğu gibi bu defa da gazetesinde hemen hemen her gün sergi hakkında tanıtım ve eleştiri içerikli yazılar kaleme aldığı görülür. Delbeuf'ün yazılarını hazırlarken kendi kanaatlerinin yanı sıra, sergi kataloğundan da bir hayli yararlandığını ekleyebiliriz. Bu yazılar bir hayli kapsamlı yazılar olarak dikkati çeker hatta yapılan yeni araştırmalar ışığında bu yazıların ayrı bir yayın olarak toplandığı tespit edilmiştir. Türk Tarih Kurumu Kütüphanesi’nde A.IV/0534 yer numarası ile kayıtlı olan bu yayın Les Artistes de Constantinople, Salon de Pera, Deuxième Année adını taşımaktadır. Söz konusu kitabın dışında yine aynı kütüphanede A/7812 yer numarası ile kayıtlı Deuxième Exposition des Artistes de Constantinople. Salon 1902, Catalogue adını taşıyan bir de sergi kataloğu bulunmaktadır. İsimleri de oldukça benzer olan bu iki eserin müellifi kuvvetle muhtemel Régis Delbeuf olmalıdır. Katalog olarak belirtilen yayının sergi ile beraber çıktığını düşünmek mümkünse de diğer kitabın Delbeuf'ün Stamboul gazetesinde günlük olarak çıkan yazılarından oluştuğu hatta, serginin günlük ziyaretçi sayılarını içerdiği dikkate alınırsa yayının sergiden sonra basılmış olduğunu kesinlik kazanır. Ayrıca bu yayın içinde hemen başta Osmanlı İmparatorluğu'nda plastik sanatların gelişimine dair yazılmış bir serbest yazı da bulunmaktadır. ${ }^{37}$

Elde edilen yeni kaynaklardan bir diğeri olan Yıldız Fotoğraf Albümlerinde karşılaşılan sergiye dair görsellerin tanımlanması yukarıda bahsedilen yayınlar ve ağırlıklı olarak da gazetelerde çıkan yazılar sayesinde gerçekleştirilmiştir. Burada hemen ifade edilmesi gerekir ki, sergi kataloğunda yer alan eser isimleriyle günümüze ulaşan eser isimleri farklılıklar göstermektedir. İsimlerindeki bu ikilik nedeniyle yapıtların tanınıp, tespit edilmesinde eser isimlerinin çok da güvenli olmadığ 1 , bu yüzden eserlere ilişkin

35 Cezar, 1995, 442.

36 Stamboul, 21 Nisan 1902.

37 Le Salon de Péra, L'Art à Constantinople, Les Artistes de Constantinople, Salon de Pera, Deuxième Année, 1902, 3-16. 
tasvirlerin temel alınması gerektiği anlaşılmıştır. Söz konusu albümlerle ilgili olarak bilinmesi gereken bir diğer husus da ilk Paris Salon Sergileri’nde olduğu gibi Pera Salon Sergileri'nde de eserlerin duvar yüzeyinde hiç boş yer kalmayacak şekilde yerden tavana kadar yerleştirilmiş olmalarıdır (Görsel 1). Bu şekilde yapılan yerleştirme nedeniyle bir fotoğraf karesine, birden fazla eserin yan yana tek bir duvar yüzeyindeki görünümleri sığdırılmıştır. Böylece eser tespiti yapılırken hangi eserin, hangi eserle birlikte sergilendiği bilgisi de görünürlük kazanmıştır. Öte yandan eserlerin yanında herhangi bir etiketleme olmadığ1 ancak bazı çerçeveler üzerinde metal plakaların bulunduğu görülmüştür.

Sergide yer alan eserlerin cismi görünümlerinin tespitine olanak veren bu albümler günümüzde İstanbul Üniversitesi Nadir Eserler Kütüphanesi'nde yer alan 90527 ve 90528 numaralı iki albümdür. Toplamda kırk kadar fotoğraf ağırlıklı olarak 1902 sergisine ait görsellerden oluşmaktadır. Fotoğraflar, mekânda ziyaretçilerin olmadığı bir zamanda çekilmiş ve büyük ihtimalle Sultan II. Abdülhamit'e sunulmak üzere hazırlanmıştır.

Fotoğraflar üzerinden yapılan değerlendirmelere geçersek ilk sırada 1902 Sergisi'ne en çok eser veren Leonardo De Mango ile başlanabilir. Sanatçının sergideki dört eserini, eserlerin bugün halen dolaşımda oldukları için kolayca tespit etmek mümkündür. Bunlar Istanbul'da bir Sokak, Öykü Anlatıcısı, Üsküdar'da Çeşme, Kız Kulesi isimli eserlerdir. Benzer şekilde Zonaro’ya ait Doğu Kostümlü Kız, Saz Çalan Kız, Bayram ve Sahilde Yürüyenler isimli yapıtlar da kolayca seçilebilmiştir (Görsel 2). Fakat günümüzde dolaşımda bulunmayan eserlerin tespit edilmesi bu kadar kolay olmadığ 1 gibi oldukça dikkatli bir karşılaştırma ve ilişkilendirme süreci gerektirmiştir. Bu aşamada öncelikle gazetelerdeki tasvir ve tariflerden hareketle her bir sanatçı için sergide yer alan eserlerinin adlarıyla eser tasvirlerinden hareketle eldeki fotoğraflardan bu tasvirleri sağlayanlar belirlenmiştir. Örneğin Halil Paşa'nın bilindik yapıtlarından Bostancı Çeşmesi ve Oğlum Halim isimli resimlerinin yanı sıra daha önce izine rastlanmadığı düşünülen Oğlum Selim ve Amazon isimli tablolarını yukarıda belirtildiği şekilde saptanmış ve böylece Amazon isimli tablonun, Üsküdar Amerikan Kız Koleji'nin müdiresi olan Bayan Patrick'in at üzerinde resmedildiği eser olduğu görülmüştür. Bu bilgiden başka albümdeki fotoğraftan yola çıkarak Halil Paşa'nın çok bilinen Madam X isimli tablosunun da Amazon isimli eserle birlikte aynı duvarda yer aldığı tespit edilmiştir (Görsel 3).

Tespiti yapılan tüm eserlere makalede yer verilemeyeceği için şimdiye kadar yapıtlarından neredeyse hiç örnek görülmemiş Vasmagidis, Alectoridis, Lemare gibi sanatçılara öncelik tanınmıştır. Böylece Vasmagidis'in serginin en dikkat çeken çalışmaları arasında gösterilen İki Büyük Martir, Geçmiş ve Gelecek için Dua isimli eserleri tespit edilmiştir. Söz konusu tablolar için Celâl Esad "terkipteki hayalperestlik" 38 tanımını kullanırken ${ }^{39}$ Delbeuf ise aşağıdaki ifadeleri kullanır:

38 Kompozisyonun bir araya getirilişindeki hayalcilik

39 Celâl bin Esad, Sergideki Resimler, İkdam 18 Nisan 1902'den akt.: Özyiğit, 2012, 182. 
Vasmagidis'in 218 numaralı eserinin adı «İnsanlığın iki büyük martiri». Alectoridis gibi o da Zonaro'nun talebesi. Bu sergi onun da ilk defa kamuoyuna çıkışı ve daha ilk seferde büyük gürültü kopardı. Her ikisi de büyük meselelere kafa yoruyor. Dindar, sofu bir yanları var. Vasmagidis de akbaba tarafından dişlenen Promete'yi ve çarmıhta İsa'yı çizmiş. Üzerlerine şöyle bir yazı eklenmiş: Her ikisi de insanlık için kendilerini feda ettiler. Biri ruh için, diğeri akıl için. Sanatçı bu ikisine «insanlık azizleri» adını vermiş. Doğrusu çok yetenekli. ${ }^{40}$

Yukarıdaki alıntıda hemen fark edileceği gibi sanatçının tabloya verdiği isimle katalogda yeralan isimler aynı değildir. Ancak bu farka rağmen eseri, biri mitolojik diğeri dini iki kahramanın birlikte aynı bağlam içinde yerleştirilmesinden tanımak mümkün olmuştur (Görsel 4). Kompozisyonun fotoğraftan görülebildiği kadarıyla sıradış1 olduğu söylenebilir. Renk paleti bilinmese de etkili 1şık kullanımıyla güçlü deseni de kendini belli etmektedir. Bu tablonun hemen sağındaki yaşlı adam portresinin yanında yer alan tabloda ise üst bedeni çıplak bir figür seçilmektedir. Bu portre Ahmet Rıfat'ın katalogda "Etüt" olarak belirtilen dört eserinden biridir (Görsel 4). ${ }^{41}$

Zonaro'nun öğrencilerinden olan Ahmet Rıfat'ın eserinin çerçevesinde görülen beyaz renkli etikete bakılırsa bu bölümdeki eser satılmıştır. Zira sergi fotoğrafları arasında bazı eserlerin çerçevesinde gelişigüzel şekilde iliştirilmiş etiketlerin anlamı bu olsa gerektir. Her iki çalışmada da erkek figürlerinin çıplak olmasına rağmen sergide nü eserin yasağının nasıl değerlendirildiği sorusunun cevabını ise Ahu Antmen'in görüşlerinden hareketle verebiliriz. Üryan, Çıplak, Nü; Türk Resminde Bir Modernleşme Öyküsü isimli serginin kataloğunda Antmen nü denilince akla gelenin erkek bedeninden ziyade kadın bedeni olduğunu söylemektedir. Antmen'in ileri sürdüğü gibi burada görülen örneklerde de tabloda çıplak ya da yarı çıplak gösterilen erkek figürleri Saray’ın yasakladığı nü eser statüsünde görülmedikleri için sergide yeralabilmişlerdir. ${ }^{42}$ Keza Warnia Zarzecki'nin Finis Vanitatum “Mutlak Son” isimli eseri için de aynı durum geçerli olmuş; tabloda baştan ayağa çıplak olarak arkadan gösterilen erkek figürü de yine nü olarak değerlendirilmemiştir (Görsel 5).

Söz konusu tablo, sanatçının bugün izi kaybedilmiş yapıtlardan biri olması ise ayrıca önem arz etmektedir. Eser hakkında Delbeuf şöyle yazmıştır:

Warnia Zarzecki, 12 eserle C salonunda yer alıyor.

Katalogda 223 numaralı eserinin adı: «Finis Vanitatum yani Mutlak Son».

İnsanlar onu her zaman kasvetli bulurlar, resmi cenaze duası gibi çok ağırdır. Eski Ahit’teki Vaiz bölümünü çağrıştırıyor sanki: Vanitas Vanitatum, Herşey boş! O da tablolarında bunu veriyor. (...)

40 Stamboul, 23 May1s 1902.

41 Deuxième Exposition des Artistes de Constantinople. Salon 1902, Catalogue, 1902, 7.

42 Antmen, 2015, 15-66. 
Sergiye gelen ziyaretçiler pek düşünmeden geziyorlar. Sanki tiyatroya gelmiş gibi seyrediyorlar. Bu tür ziyaretçiler ressamın değerini anlamamış olabilirler. Ama düşünmeyi sevenler bu eserin hakkını verir. Sonuçta bu eser, salonun baş eserlerinden biri. ${ }^{43}$

Delbeuf'ün dikkat çektiği tablo hiç kuşkusuz serginin en özel çalışmalarından biridir. Zira 16. Yüzyılda sıklıkla görülen Vanitas sembollerinden hareketle geliştirildiği anlaşılan kompozisyonda Warnia Zarzecki, çerçeveyi de resimlemiş ve bu kısma da kuru kafa tasvirleri eklemiştir. Kırık araba tekerlekleri ve yıkıntılar içinde mezar taşlarının arasında 1şığa doğru yürüyen erkek figürü ise kompozisyonun tek figürüdür. Sağ üst köşede ressamın, tuval üzerine Finis Vanitatum yazısını eklediği görülmektedir. Celâl Esad, sanatçının resmini felsefi bir sembol olarak gördüğünü ifade ederek Warnia'nın ressamlığında şiir ve felsefenin ne denli etkili olduğuna değinmiştir. ${ }^{44}$

Serginin en güçlü çalışmalarından bir diğeri ise Delbeuf'e göre genç sanatçı Alectoridis'e aittir. Sanatçının bu tablosu yine Delbeuf'ün detaylı tasviri sayesinde tespit edilebilmiştir. Biri yaşı diğeri genç iki kadını dua eder halde gösteren bu tablo için (Görsel 6) Delbeuf şöyle yazmıştır:

Alectoridis İstanbul doğumlu ve Zonaro'nun öğrencisi. 26 numaralı eserinin adı «Geçmiş ve gelecek için dua». Şapka çıkarılması gereken bir sanatçı, onun eserlerini ayırt etmek için profesyonel olmaya gerek yok. Mösyö Constans mesela salona girip daha iki adım atar atmaz bu tablonun önüne gelip, sordu:

-Bu kimin?

-Yeni başlamış bir öğrencinin

-Artık yeni başlamış sayılmaz!

Elinde katalog olmadan gezen herkes gelip bu tablonun önünde durdu, kimin diye sordu. Kataloğu hazırlayan tabloya bu ismi vermiş. İki kadın dua ediyorlar; bir tan ağarması gibi gönül okşayıc1, ellerini havaya kaldırmış. (...) Diğeri annesi yaşlı ve artık örtünmüş, yas örtüsü takıyor. Bir ikona eğilmiş, kaybettikleri için dua ediyor.(...) İşte 1902 sergisinin ödülünü alacak eser! Tabi eğer bir jüri olsaydı! ${ }^{45}$

Yazının sonunda Delbeuf'ün değindiği gibi Salon Sergisi'nde bir jüri olması gerektiği konusu Celâl Esad'ın da hem fikir olduğu bir konudur. Celâl Esad, beynelmilel sergilerde eserlerin jüri tarafından seçildiğinden ve ödül verilmesi söz konusu olduğunda da yine jürinin rol aldığından bahsederken bu uygulamamaların Pera Salonları'nda da olması gerektiğinin altını çizmektedir. ${ }^{46}$

43 Stamboul, 24 May1s 1902.

44 Celâl bin Esad, Sergideki Resimler, İkdam 18 Nisan 1902'den akt.: Özyiğit, 2012, 189.

45 Stamboul, 23 Nisan 1902.

46 Özyiğit, 2012, 225, 288 
1902 Sergisi'nde tespit edilen tablolardan bir diğerinde, üzerine madalyalar iliştirilmiş smokiniyle duran bir orkestra şefi, elini bir nota sehpasına dayar vaziyette gösterilmiştir (Görsel 7). Nota sehpasındaki eser defterinde ise Parsifal ve Wagner yazılıdır. Tablonun kime ait olduğunu anlamak için kataloğa bakıldığında "orkestra şefi”" gibi bir tabir kullanılmadığını ancak Paul Giese isimli sanatçının eserleri arasında 107 numaralı eser için Paul Lange'ın portresi adının inachevé yani "bitmemiş" ibaresiyle birlikte yazıldığı görülmektedir. ${ }^{47}$ Paul Lange, Mızıka-i Hümayun'da şeflik yapmış, 1890'larda ise Üsküdar Amerikan Kız Koleji'nde öğretmen olarak çalıştıktan sonra vefat ettiği 1920 yılına kadar İstanbul'da yaşamıştır. Bu bilgiden hareketle Paul Lange'ın sima olarak bu kişi olup olmadığını da müzisyenin bir fotoğrafından teyit edildiğini belirtmek gerekir. Bu şekilde tablonun ismi ve cismî görüntüsünü eşleştirdikten sonra resmin içeriğine odaklanıldığında akla şu soru gelmiştir; Acaba ressam Paul Giese, Paul Lange'ı resmederken bir temenniyi, bir hayali mi çizmiştir yoksa gerçekleşmiş bir sahneyi mi canlandırmıştır? Bu sorunun önemi şuradadır zira bilindiği gibi Wagner'in Parsifal isimli bestesi son yapıtı olmakla beraber eserin icrasına ilişkin bir vasiyet söz konusudur; Wagner, Parsifal operasının sadece Wagner eserlerinin çalınması için inşa edilmiş Bayreuth kentindeki Festspielhause'da çalınmasına müsaade etmiş, başka bir yerde Parsifal'in çalınmasını da vasiyetiyle yasaklamıştır. O halde Paul Lange bu eserin çalınmasında gerçekten rol almış mıdır? Sorunun cevabı yine basın kanalından gelecektir. 1902 sergisinden üç yıl kadar önce 1899 yılı Temmuz ayında yayınlanan Bayreuther Blatter isimli dergiden Ömer Egecioğlu'nun yaptığı alıntıya göre 24 Mart 1899 tarihinde, İstanbul'da Paul Lange yönetimindeki koro, Parsifal'in koral bölümlerinin bir kısmını seslendirmiştir. ${ }^{48}$ İstanbul Rum Edebiyat Cemiyeti'ne (Le Syllogue Littéraire Grec de Constantinople) ait Balıkpazarı Topçular Sokak 18 numaradaki lokalde gerçekleştirilen dinleti, ayrıca Londra ve New York’taki müzik dergilerinde de konu edilecek kadar ilgi çekici olmuştur. Bu durumda söz konusu tablonun gerçekleşmiş bir olayı konu aldığını ve de tarihi bir belge olarak da anlam kazandığını söylemek mümkündür. Öte yandan Parsifal'in tümünün değil ama bir kısmının vasiyet dışında İstanbul'da seslendirilmesiyle ilgili olarak kendisi de Alman olan Paul Lange'1n mazur görülmesinde belki de Sultan Abdülaziz'in Wagner'e kendi konser salonunu yaparken yaşadığı maddi sıkıntıyı gidermesi için gönderdiği 900 thaler (günümüzde yaklaşık 20bin euro) tutarındaki bağ 1 şın ${ }^{49}$ hatırı söz konusu olmuştur.

İlginç olan bir başka konu ise bugün bizi meraklandıran Paul Lange portresinin ne Celâl Esad ne de Delbeuf tarafından o gün o kadar da ilginç bulunmayış1dır. Zira ikisi de bu portreden hiç bahsetmezken sadece Celâl Esad, Paul Giese'e ait Durgun Göl isimli eseri hakkında (ki Paul Lange portresinin hemen sağında asılıdır) şunları kaleme almıştır:

47 Deuxième Exposition des Artistes de Constantinople. Salon 1902, Catalogue, 1902, 15.

48 Egecioğlu, “Eski İstanbul'da Parsifal'den Seçmeler”, Opus Klasik Müzik Dergisi, 15 Aralık 2014-15 Ocak 2015, 62-66.

49 Emre Aracı, bahsi geçen bağışın belgelerini Alman arşivinde bulmuş ve bu belgeleri Andante dergisinin Aralık 2003-Ocak 2004 tarihli 8. sayısında "Dolmabahçe'den Bayreuth'a Uzanan Yardım Eli” başlıklı makalesinde paylaşmıştır. 
Gecenin maviliğini giymiş bir göl, bu su içinden firlamış sazlar içinde bir peri, elinde harp. Gölün bir tarafında bulunan hane içinde kızıl bir ışık. Köşkten göle doğru uzun büyük merdivenlerde birçok timsal-i ruh harpın sedasını dinleyerek yavaş yavaş merdivenlerden iniyorlar. Kimi bu mavi göle girmiş, kimi girmek üzere. Kimi başına kadar gömülmüş, gözlerini kapamış, uykuya dalmış. Filhakika insan da uykuya daldığı vakit tatlı bir nağmenin hatırasıyla okşanan ruhi bir hal ile kendinden geçer ki işte bu tablodaki fikr-i takdir hayali ise gerek renkler ve gerek eşkâl de o kadar gariptir. Şüphesizdir ki tab'iatta böyle bir levhaya asla tesadüf edilemez. Zaten bir mahsul-ü hayal olan böyle tasviri olan bir fikri de ancak bu suretle resmetmek muvafik olur. ${ }^{50}$

Celâl Esad'ın sözünü ettiği bu tablo katalogda 105 numara ile kayıtlı Durgun Göl isimli tablodur (Görsel 7). Yazara göre bu sahne gerçek hayatta olabilecek bir görüntü değildir. Ancak tablo izleyici üzerinde etki bırakacak güce sahiptir.

Sergiye yurtdışından katılan ve adından pek az bahsedilen bir başka isimse Georges Lemare'dır. Delbeuf'ün aktardığına göre sergiden birkaç gün önce Tunus'tan İstanbul'a gelen Fransız sanatçı, Normandiya doğumludur. Delbeuf, Lemare'dan doğunun 1şı̆̆ını anlamış biri olarak bahseder. ${ }^{51}$ Sergide Lemare'ın biri Fransa'dan, dördü Tunus'tan toplam beş manzara resmi, bir çocuk başı etütü ile bir de Eskrim Hocası olarak isimlendirilmiş portre çalışması yer alır. St. Cucufat'ta bir Göl isimli tablo ise Lemare'in eşinin imzasıyla sergilenmiştir. Bu yapıtlardan sadece Eskrim Hocası isimli eseri fotoğraf albümü içinde tespit edilebilmiştir (Görsel 1).

Yukarıda eserlerinin görsellerine yer verilen sanatçıların yanı sıra albümlerdeki görsellerden Hilda Guarracino (paravan), Halil Paşa (Oğlum Selim, Oğlum Halim), Şevket Bey (Aya Sofya), Salvatore Valeri (Saka, Deve, Eşek, Yaşlı adam, Genç kadın), Osgan Efendi (Asker Selamı, Dans eden Zeybek), Warnia Zarzecki (Yvonne, Zavallı kardeşim Kathina, Seyyar Berber, Çeşme başında küçük Çingene 1 ve 2, Derviş, Güle güle Maria / Görsel 5), Thalia Floras (Doktor F'nin Portresi, Matmazel TH'nin portresi, Mavi Prenses, Genç kız / Görsel 1) ve Şeker Ahmet Ali Paşa’ya ait başka eserler de belirlenmiş ancak makalede hepsinin görseline yer verilememiştir.

\section{Salon Sergisi}

Üçüncü Salon Sergisi 24 Nisan - 24 Mayıs 1903 tarihleri arasında yine Pera Caddesi 417 numaralı binada gerçekleştirilmiştir. Önceki iki sergide olduğu gibi bu sergi de hayli ilgi çekmiştir. Nitekim toplamda 32 sanatçının katıldığı sergide mimari projeler hariç 230 kadar eser yer almış ve sergiyi açık kaldığ1 süre boyunca biletli 10217 kişi ziyaret etmiştir. ${ }^{52} \mathrm{Bu}$ rakamsal verilere bakarak üçüncü sergide eser sayısının azalmış

50 Celâl bin Esad, İkdam 18 Nisan 1902 aktaran Özyiğit 2012, 188-189.

51 Stamboul, 9 May1s 1902.

52 Cezar, 1995, 443-444. 
olmasına karşın izleyici sayısında büyük bir fark oluşmadığı söylenebilir. Ancak bu rakamları kenara koyup katılımcı listesine bakıldığında üçüncü serginin diğer ikisinden farklı olduğu hemen göze çarpmaktadır. Şöyle ki 1903 Sergisi'nde Thalia Floras, Lina Gabuzzi, De Forcade, Paul Giese, Vasmagidis, Alectoridis, Zonaro, Şeker Ahmet Ali Paşa ve Osman Hamdi Bey gibi isimler yer almamıştır. Buna mukabil 32 katılımcının yarısı kadar ismin (Ahmet Münip, Şevki Bey, Rıza Raşit, Said, Vensan (Viçen) Aslanyan, Maksimilyan Bertozzi, De Belarbre, George Gramadanis, O. Miaser, S. Valdorp, Mithad Rebii, Madam Comte Calix, Ermenak Kolanciyan, Kirkor Ütücüyan, Patrokı1 Kampanaki ve Gulio Mongeri) daha önceki iki sergiye katılmamış olmaları ise ayrıca düşündürücüdür. Verilen isimler arasında Bertozzi ve De Belarbre'ın sergiye yurtdışından katılmış oldukları anlaşılmaktadır. Sergide yer alan diğer isimlerse Ömer Adil Bey, Ahmet Ziya Bey, Şevket Bey, Albay Halil Bey, Hamdi Kenan, İzzet Tepedelendioğlu Kamil, Rıfat, Anna Aslan, Bello, L. De Mango, Madam Desgozi, Madam Riçi Montanyani, Matmazel Labella, Salvator Valeri, Lorenzo Valeri ve Warnia Zarzecki' dir. Singer firması da sergiye desen çizimlerinden örnekler göndererek bir nevi tüzel kişilik olarak iştirak etmiştir. 1903 Sergisi'nde görülen bu durumu açıklamak üzere gazetelere bakıldığında Malumat gazetesinde Celâl Esad'ın serginin katılımcıları hakkındaki yazısı önem kazanır. Yazar neden bu sergiye bazı isimlerin katılmadığını şöyle açıklar:

Kendi asar-1 (eserler) harikuladelerinin bir takım asar-1 mübtediye (acemi eserler) arasında bulunmasını istemeyenler ve bazılarının söylediğine göre resim sergisi değil resim pazarı şeklini almış olan bu sergide resim teşhiri bir ressam için kadrini tezyid (çoğaltma) değil belki azaltacağına kadar düşünerek imtina edenler ve başka sebepler gösterenler de oldu. ${ }^{53}$

Bu sözlerden anlaşıldığına göre 1903 Sergisi bir protestoya zemin olmuş; bazı eserlerin değerini kendi eserlerinden düşük gören kimi sanatçılar sergiyi resim pazarı olarak nitelendirmişlerdir. Bu konuda sergi sırasında değil ama sergi bittikten sonra bir değerlendirme yazısı yayımlayan Le Moniteur Oriental (The Oriental Advertiser) isimli gazete ise sergiye kabul edilecek eserler konusunda yeni bir uygulama olarak düzenleme komitesinin daha önce hiç sergilenmemiş eserleri sergiye kabul etme kararı aldığını, hal böyle olunca da bazı sanatçıların yeni eser yapmaya vakit bulamadıkları için sergide yer alamadıklarını ifade etmiştir. ${ }^{54}$ Ancak Alectoridis ve De Forcade gibi ressamları ayırarak onların aynı tarihlerde Atina'daki bir sergiye eser gönderdikleri için bu sene salonda olamadıklarını ekleyen Le Moniteur Oriental, Zonaro gibi sürekli resim üreten bir ismin neden yer almadığına ise tam bir açıklık getirmemiştir. Bu sorunun cevabı Zonaro'nun günlüklerinden okunmaktadır. Zonaro'nun anlatımına göre serginin düzenlenme sürecinde birtakım anlaşmazlıklar yaşanmış ve olaylar Zonaro'nun penceresinden şöyle gelişmiştir:

Serginin hazırlıkları devam ederken, maddi sıkıntı içinde olduklarını fark ettim. Mimar Vallaury serginin sorumlusu idi. Bunun üzerine kendilerine bir yıl önceki gibi bir piyango düzenlenmesini önerdim. $\mathrm{Bu}$

53 Celal bin Esad, Resim Meraklılarına Bir İki Söz, Malumat'tan akt.: Özyiğit, 2012, 289.

54 Le Moniteur Oriental / The Oriental Advertiser, 3 Haziran 1903. 
önerim kabul gördü ve piyango için bir de kompozisyon hazırladım. Bu kompozisyonu içeren 1000 tane numaralı bileti İtalya'da bastırdım. Çizdiğim kompozisyondaki kadının başındaki yarımay sansüre takıldı. Gümrükten bu biletleri alabilmek için üç talebemle birlikte orada oturup bu yarımayları tek tek sildik. Bunları sergiye katılan ressamlara, bir mecidiye karşılığında satmaları için 20'şer adet dağıttım. Kendilerinden de salon kirası ve masraflar için birer lira topladım. Bilet sahipleri sergi sırasında süresiz galeriyi gezebileceklerdi ve çekilecek piyangoda kazanan talihliye, sergilenen tablolardan biri armağan edilecekti. Ressamlardan yaklaşık 40 lira toplandı. Bunun üzerine Sergi Komitesi Sekreteri Polonya asıllı Alman Ressam Warnia-Zarzecki ile iki İtalyan ressam Pietro Bello ve Leonardo de Mango, Akaretler'deki atölyeme gelerek, ressamlardan toplanan parayı istediler. Buna gerekçe olarak da toplanmakta olan paranın benim evim yerine, Sergi Komitesi'nin kasasında daha güvenli korunabileceğini ileri sürdüler. Böylesi bir tavır karşısında, terbiyesizlik eden ve bana hakaret etmeye kalkışan ressam Zarzecki’ye bir kaplan gibi karşılık verdim. Yanımdaki iki öğrencim de J. Warnia-Zarzecki'ye büyük tepki gösterdiler. Gösterdiğimiz tepki karşısında, J. Warnia Zarzecki ve P. Bello ile L. de Mango öfkeyle evimden çıkıp gittiler. Ertesi gün öğrencilerimin de yardımıyla, bütün ressamları tek tek ziyaret ederek toplanan parayı iade ettim. Bu olaydan sonra, benim gibi birçok tanınmış ressam hoşnutsuzluklarını göstermek için, 1903 yılında düzenlenen sergiye katılmadılar ve bir daha da sergi düzenlenemedi. ${ }^{55}$

Günlükteki notlara bakılırsa Düzenleme Komitesi ile Zonaro arasında sergi mekân kirası için sanatçılardan toplanan paralar nedeniyle bir tartışma yaşanmış olduğu anlaşılmaktadır. Yaşanan tartışma bütün boyutlarıyla tam bir netliğe kavuşturulamamış olmakla beraber, 1903 Sergisi'nden sonra aynı ismi koruyan sergilerin yapılmadığına bakarak, gerilimin salonların kaderini belirleyecek kadar derin olduğunu düşünmek mümkündür.

Konu hakkında başka ipuçları yakalamak amacıyla yaşananların uzaktan fakat bir o kadar da yakından takipçisi Adolphe Thalasso'nun yazdıklarına bakıldığında ise Üçüncü Salon Sergisi hakkında dolaylı ifadeler kullandığı görülür. Ağırlıklı olarak ilk serginin üzerinde duran Thalasso, sergileri konu aldığı yazısının sonlarında salonların sona erişini büyük bir talihsizlik olarak nitelendirirken Levantenler olarak tanımladığı ancak isim zikretmediği sanatçılar hakkında onları duygusuz, kıskanç ve entrikacı olarak yaftalar ve şunları yazar:

Müze-i Hümayun yanında, bir Osmanlı Ulusal Resim Heykel Müzesi kurulması hayal edilirken, 1903 Salonu birdenbire hiç de bir sebep gösterilmeden sonlandı. 1904'te tam bir bozgun yaşandi. Ressamlar, heykeltıraşlar öyle bir karanlığa gömüldüler ki, bundan böyle Salon bahsi kapandı artık. İstanbul Salonları, bir zamanlardı. (...) Bu oluşum

55 Öndeş ve Makzume, 2003, 60. 
(sergileri kastediyor) hiç yoktan var olmuş bir gelişmeydi. Gelecekte sürgün verecek bir tohumdu toprağa atılmış. Bundan alınacak haz, sanatçıları destekleyecek, halkı yavaş yavaş güzel şeylere yaklaştıracaktı. Türk Halkının plastik sanatlar konusundaki cehaleti, entelektüel çaba gerektiren mevzularda Levantenlerin kasvet veren duygusuzlukları, kıskançlıklar, entrikalar, çevrilen dolaplar bu çöküşü hazırladı. ${ }^{56}$

$\mathrm{Bu}$ hadiseleri kenara koyup sergi içeriğine dönersek ilk salon sergisinde sayıca fazla görülen manzara resimlerinin bu sergide de yüksek olduğu söylenebilir. Manzaraların konusu hemen hemen tamamen İstanbul'dur. Boğaz, Sarayburnu, Göksu, Üsküdar, çeşitli sokak görümleri, evler, mezarlıklar, korular, deniz manzaraları en çok işlenmiş konulardır. Teknik olaraksa suluboya ve pastel türü işlerin sayısı bu üçüncü sergide öncekilere göre daha fazladır. Eserlerin konu içerikleri ise Düzenleme Komitesi'nin daha önce hiçbir yerde sergilenmemiş eserlerin bu salona kabul edileceği kararına rağmen bir çeşitlilik göstermez. Öte yandan ilk iki sergide göz dolduran yapıtların sahibi olan birçok ismin bu sergide yer almaması nitelik açısından sergiyi geriye düşürmüşe benzemektedir. Komitenin koyduğu kural gereği hiç sergilenmemiş eser getirme gayesiyle sergiye eser gönderen yeni isimlerin, sonraki yıllarda hiç varlık gösterememiş olmaları ise bu kişilerin amatör bir çizgide kaldıkları savını doğrular.

1903 Sergisi "Resim”, “Gravür ve El işleme”, "Mimarlık” olarak üç bölüme ayrılmıştır. Halil Özyiğit' in belirttiğine göre sergi kataloğu bu defa çift dilli Osmanlıca ve Fransızca olarak düzenlenmiştir. ${ }^{57} \mathrm{Bu}$ durum izleyiciler arasında Fransızca bilmeyen kesimin sayıca arttığına dair bir ipucu olarak yorumlanabilir. Sergide resim bölümünde 26 sanatçıya ait 191 eser yer alırken, Gravür ve El işleme bölümünde Singer ticarethanesi hariç 5 sanatçının 38 çalışması, Mimari kısmında ise 4 kişiye ait 55 çizim yer aldığ belirtilmiştir. ${ }^{58}$ Tüm rakamlar toplandığında Singer Ticarethanesini ve hem Resim bölümünde hem Mimari bölümde işleri olan Bello’yu tek katılımcı olarak sayıldığında katılımcı sayısı 33 olarak tespit edilir. Kadın katılımcılar ise Anna Aslan, Madam Desgozi, Madam Labella, Madam V. Comte ve Madam Marie de Ricci Montagnani'dir. Sergide ilk defa adı duyulanlar arasında Midhat Rebii, Armenak Kolanciyan Sanayi-i Nefise'de yetişmiş gravür sanatçıları olarak gösterilirken Kirkor Ütücüyan ise yine gravür alanında özel dersler alarak kendini yetiştirmiş biri olarak tanıtılmıştır. Mimarlık başlığı altında Bello'nun yanı sıra görülen Lorenzo Valeri, Salvatore Valeri'nin kardeşidir. Gulio Mongeri ve Patrokli Kampanaki ise İstanbul'da eserleri olan önemli mimarlardandır. Kampanaki'nin en önemli yapıtı İstiklal Caddesi üzerindeki Ses Tiyatrosu'dur. Mongeri ise Cumhuriyet Dönemi'nde I. Ulusal Mimari Akımının güçlü isimlerinden biri olmakla beraber Beyoğlu'ndaki St. Antoine Kilisesi'nin mimarı olarak tanınacaktır.

Mimari tasvirlerin sahiplerine bakıldığında özellikle Kampanaki'nin Mısır'dan Londra'ya, Kaliforniya'dan Burgazada'ya kadar çeşitli coğrafyalarda yeralacak projelere dair çizimlerinin göz doldurduğunu söylemek mümkündür. Ancak eleştiri yazılarına

56 Thalasso, 1906, 180-181.

57 Özyiğit, 2012, 495.

58 Özyiğit, 2012, 483-502. 
bakılırsa bu farklı ve zengin içerikli Mimari Bölümü, serginin geneline hakim olan vasat görüntüyü değiştirmeye yetmemiştir. Nitekim Celâl Esad, en çok bu konuda hayal kırıklığına uğradığını belirttiği yazısında "Bütün İstanbul halkınca kemal-i takdir ile seyir ve temaşa edilecek birçok Osmanlı ressamının eser teşhir etmemeleri hiçbir vecihle nazar-1 müsahama ile görülecek husustan değildir." diyerek sergiye katılmayan sanatçıları mazur görmediğini ifade etmiş, sergide kendini gösteren yeni isimlere de kompozisyonlarını geliştirmeleri, farklı konulara ve de büyük boyutlu çalışmalara yönelmeleri nasihatinde bulunmuştur. Celâl Esad için bu sergide en çok takdir edilmesi gereken kişi de diğer sanatçılar gibi "kapris yapmayan" ve sergiye katılmamazlık etmeyen Halil Paşa'dır. Onun gibi uluslararası sergi tecrübesi olan bir zatın kibre kapılmadan eserlerini sergiye göndermesini bu nedenle örnek alınacak bir tavır olarak gösterir. ${ }^{59}$

Celâl Esad'ın 1903 Sergisi yazılarında öncekilerde olduğu gibi yine tek tek sanatçıları konu ettiği görülür. Ancak isimleri bu defa gelişi güzel sıralamıştır. Ömer Adil Bey'den sonra Warnia Zarzecki'ye geçen yazarın yazısını yazarken sergi kataloğundaki sıralamayı takip ederek değil, sergiyi gezdiği sırada kendi aldığı notlardan yararlandığını düşünmek mümkündür. Zira 90527 numaralı albümde 10 numaralı kart üzerinde Warnia'nın portreleri ile Ömer Adil Bey'in katalogda 15 numaralı "Resimhanede" isimli eseri aynı duvarda asılı olarak görülmektedir. Dolayısıyla Celâl Esad'ın aynı duvar üzerinde gördüğü iki farklı sanatçıya ait eserleri, yazısında peş peşe tanıtmasından sergiyi kendi gezdiği ve gördüğü sırada aktardığı anlaşılır. Celâl Esad, eleştirilerini yükselttiği Warnia Zarzecki hakkında, sanatçının her biri farklı ruh halleri içinde gösterilmiş portreler yapmak yerine, bu portreleri birlikte gösterecek daha büyük kompozisyonlar yapmasının daha isabetli olacağını söyler. ${ }^{60} \mathrm{Bu}$ grup portreler arasında sanatçının Silence "Sükut" olarak adlandırılan tablosu 90527 envanter numaralı albümde diğer portrelerle birlikte net olarak görülmektedir (Görsel 8).

1903 Sergisi'ne katılan isimlerden biri olan Şevket Bey ise Ayasofya'nın içini gösteren tablolarıyla takdir toplar (Görsel 9). Nitekim ileride diğer katılımcılardan farklı olarak adını resim tarihi içinde kalıcı olarak yazdıracak olan Şevket Bey (Şevket Dağ) 1916 yılında düzenlenen Galatasaray Sergileri'nin de mimarlarından biri olacaktır. Diğer bir deyişle 1902 ve 1903 Sergileri kendisi için iyi bir başlangıç olmuş, güçlü tablolarıyla sonraki sergilerde de kendine yer bulmuştur. 1903 Sergisi'ne ait değerlendirilecek son fotoğrafta ise Valeri'nin öğrencisi Ohannes Miasseryan’a ait ve “O. Miasser” imzasıyla "Meyve" isimli natürmort hemen fark edilmektedir (Görsel 10).

Makalenin başlarında belirtildiği gibi 90527 numaralı albümün içinde yer alan fotoğrafların çoğu 1902 sergisine ait olduğu için 1903 sergisine ilişkin kısıtlı sayıda fotoğraf görülmüştür. Serginin gerçekleştiği dönemi içine alan Stamboul gazetesinin 1903 yılı Ocak-Temmuz arasını kapsayan birinci cildine de erişilemediği için Delbeuf'ün tanıklığı bu bölümde eksik kalmıştır.

59 Özyiğit, 2012, 288-291.

60 Özyiğit, 2012, 294. 


\section{Sonuç}

Akademik araştırmaların birbirlerini beslemesi esasına uygun olarak hazırlanan makalede, her biri büyük emek içeren iki doktora tezinin ${ }^{61}$ ortaya çıkardığı basın kaynakları temel alınarak, son yıllarda erişilen sergi katalogları ile fotoğraf albümleri elde edilen verilerin birbirini bütünleyebilmesine yönelik olarak değerlendirilmiştir. Bu doğrultuda ağırlıklı olarak Stamboul gazetesinin başyazarı Régis Delbeuf'ün yazıları ile İkdam ve Malumat'taki Celâl Esad'ın yazıları makalenin ana aksını oluşturmuş, sergi katalogları ve fotoğraflarsa sergilerin somut bir görünüm kazanmasına katkı sunmuşlardır.

Sergiler özelinde sonuç değerlendirmesinde araştırmaya konu olan Pera Salon Sergileri'ne katılmış toplam sanatçı sayısı 70 olarak tespit edilmiştir. Üç sergiye de katılan sanatçı sayısı ise 6 olarak tespit edilmiştir. Bu isimler Ömer Adil Bey, Halil Paşa, Philippo Bello, Leonardo De Mango, Salvatore Valeri ve Joseph Warnia Zarzecki olarak kayda alınmıştır. Birbirini takip etmesine rağmen üç serginin de basındaki eleştirmenler nazarında farklı etkileri olduğu görülmüş, en çok vurgu yapılan serginin ise ikinci salon sergisi olduğu yargısına varılmıştır. Bu nedenle makale kapsamında da ağırlıklı olarak ikinci sergiye ait albümlerdeki görsellerden yapılan tespitlere ağırlık verilmiştir. Böylece bugün pek çoğuna erişilmemiş olan eserlerin görüntüleri üzerinden sanatçıları daha iyi değerlendirme imkânı da doğmuştur. Daha somutlaştıracak olursak örneğin Warnia Zarzecki'nin Finis Vanitatum "Mutlak Son” tablosunda olduğu gibi 16. Yüzyılda bir dönem etkili olmuş Vanitas sembollerine 19. Yüzyıl sonlarında İstanbul'da yapılmış bir tablo ile atıfta bulunulduğunu görmek, ya da erken Fovist resim örneklerinin Avrupa'da bile akımın daha tanımlanmadığı bir zamanda İstanbul'da izleyiciye sunulmuş olduğu fark etmek, Pera Salon Sergileri'nin ne denli zengin bir içeriğe sahip olduğuna işaret etmektedir. Paris'te Adolphe Thalasso'nun yazılarını yayımlandığg L'Art et Les Artistes dergisindeki köşesinde sıklıkla bahsettiği gibi aslında İstanbul, Kırım Savaşı'ndan itibaren Avrupa'da da önemli bir merkez nokta olduğunu Salon Sergileriyle tekrar gözler önüne sermiştir. Nitekim çok kalabalık olmasalar da bazı Avrupa'lı sanatçıların sergilere rağbet etmesi de böyle bir kabulle ilgili olsa gerektir.

Bazı sanat eserlerinin salt barındırdığı estetik değerle değil, içeriğine bağlı olarak tarihi bir belge olarak da değerlendirilebileceği fikri ise Paul Giese'in Paul Lange portresiyle yerel ortamda güçlenmiştir. Katılımcı çeşitliliğinin yanı sıra eser içeriklerindeki zenginlik de Avrupa resim tarihine göre oldukça kısa bir geçmişe sahip plastik sanatlar tarihimizde, Salon Sergileri özelinde hayli çarpıcı bir noktaya ulaşmıştır. Yıllarca tasvir yasağı bağlamında en çok portreye mesafeli durulan bir toplumda kısa sürede yaşanan dönüşümle, portrelerin sergilerde manzara resimleriyle başa baş oluşu da ayrica not edilmelidir.

Son olarak Osmanlı İmparatorluğu'nun en kozmopolit kenti payitaht İstanbul'da, hatta daha da dar kapsamda 19. Yüzyılda Pera'da cereyan eden sanatsal faaliyetlere dair öykülerden hareketle, insan ilişkilerine dair önemli detayların açığa çıkması

61 Sinanlar, 2008; Özyiğit, 2012. 
mümkün olmuştur. Bir yanda, Le Figaro'nun muhabiri olarak İstanbul'a gelmiş Fransız gazeteci Régis Delbeuf ile İstanbul'dan Paris'e göçmüş Levanten entelektüel Adolphe Thalasso'nun, Pera Sergileri ortak paydasında buluşmaları önem kazanırken, bir yanda resim pratiğinin hayli geç tatbik edilmeye başlandığı İstanbul'da, sanatın gelişmesi için büyük çaba ve fikir ortaya koyan kendisi de ressam Celâl Esad'in değerlendirmelerinin ne denli güçlü ve önemli olduğu bir kere daha görülmüştür. İlişkiler açısından ise Saray Ressamı unvanlı Fausto Zonaro ile Sanayi-i Nefise Mektebi'nin sanatçı hocalarının önceleri iş birliği içindeyken birden kopma noktasına gelişleri ise resim tarihimizdeki ilk "sergiye katılmama protestosuna" neden olması bakımından önem teşkil etmiştir. $\mathrm{Bu}$ olayların hepsi birlikte okunduğunda Pera merkezli gelişen Osmanlı plastik sanatlar dünyasının ne denli zengin bir içeriğe ve de ne kadar çok katmanlı anlatılara sahip olduğu anlaşılmaktadır. 


\section{KAYNAKÇA}

Antmen, A. (2008). 20. Yüzyıl Batı Sanatında Akımlar, İstanbul: Sel Yayıncılık.

Antmen, A. (2015). Üryan, Çıplak, Nü, Türk Resminde Bir Modernleşme Öyküsü, İstanbul: Pera Müzesi Yayınları No:79.

Arac1, E. (2004). Dolmabahçe'den Bayreuth'a Uzanan Yardım Eli. Andante, 8, 29-31.

Cezar, M. (1995). Sanatta Batıya Açılış ve Osman Hamdi Bey. İstanbul: Türk Kültürüne Hizmet Vakfı Sanat Yayınları.

Egecioğlu, Ö. (2014-2015). Eski İstanbul'da Parsifal'den Seçmeler. Opus Klasik Müzik Dergisi, 15 Aralık 2014-15 Ocak 2015, 62-66.

Erten, O. (2012). Türk Sanatına Yön Veren Sergiler ve Yahşi Baraz’ın Büyük Sergileri, c.1, İstanbul: 47-52.

Öndeş, O ve Makzume E. (2003). Osmanlı Saray Ressamı Fausto Zonaro, İstanbul: Yapı Kredi Yayınları.

Özyiğit, H. (2012). 1830-1920 Yılları arasında süreli yayınlarda Türk resim sanatı eleştirisi, Ankara Üniversitesi, Sosyal Bilimler Enstitüsü, Sanat Tarihi Anabilim dalı, yayımlanmamış doktora tezi, Ankara.

Le Moniteur Oriental / The Oriental Advertiser (İstanbul Atatürk Kitaplı̆̆g) 3 Haziran 1903.

Sinanlar, S., (2008). Pera'da Resim Üretim Ortamı 1844-1916. İstanbul: İstanbul Teknik Üniversitesi, Sosyal Bilimler Enstitüsü, Sanat Tarihi Anabilim Dal1, Doktora Tezi.

Sinanlar, S., (2009), Lecomte Prétextat; un homme de l'art au XIXème siècle à Péra, (İstanbul: Gerflint), Synergie Turquie No: 2, 59-67.

Sinanlar Uslu, S. (2013). Un critique français à Constantinople : Régis Delbeuf:1854-1911, İstanbul : Synergies Turquie, No: 6, 141-150.

Sinanlar Uslu, S. (2014). Adolphe Thalasso'nun gözünden Meşrutiyetin Osmanlı Sanat Ortamına Yansimaları 1908-1914, Semra Germaner Armağanı, İstanbul : MSGSÜ Yayınları, 261-272.

Stamboul: Journal Politique et litteraire (Bibliotheque National de France) 13 May1s 1901 / 16 May1s 1901 / 17 May1s 1901 / 18 May1s 1901 / 22 Mayıs 1901 / 29 Mayıs 1901 / 28 Haziran 1901 / 12 Haziran 1901/ 15 Haziran 1901 / 28 Haziran 1901 / 9 Aralık 1901 / 4 Nisan 1902 / 21 Nisan 1902 / 23 Nisan 1902 / 26 Nisan 1902 / 9 May1s 1902 / 23 Mayıs 1902 / 24 May1s 1902.

Thalasso, A. (1906). Les Premiers Salons de Peinture de Constantinople, L'Art et les Artistes, Paris: 172-181. 


\section{Yararlanılan Arşivler}

Deuxième Exposition des Artistes de Constantinople, Salon 1902, Catalogue (Türk Tarih Kurumu Kütüphanesi A/7812)

Les Artistes de Constantinople, Salon de Pera, Deuxième Année, 1902. (Türk Tarih Kurumu Kütüphanesi A.IV/0534)

Y1ldız Sarayı Fotoğraf Albümleri, 90527 ve 90528 numaralı albümler (İstanbul Nadir Eserler Kütüphanesi) 


\section{GÖRSELLER}

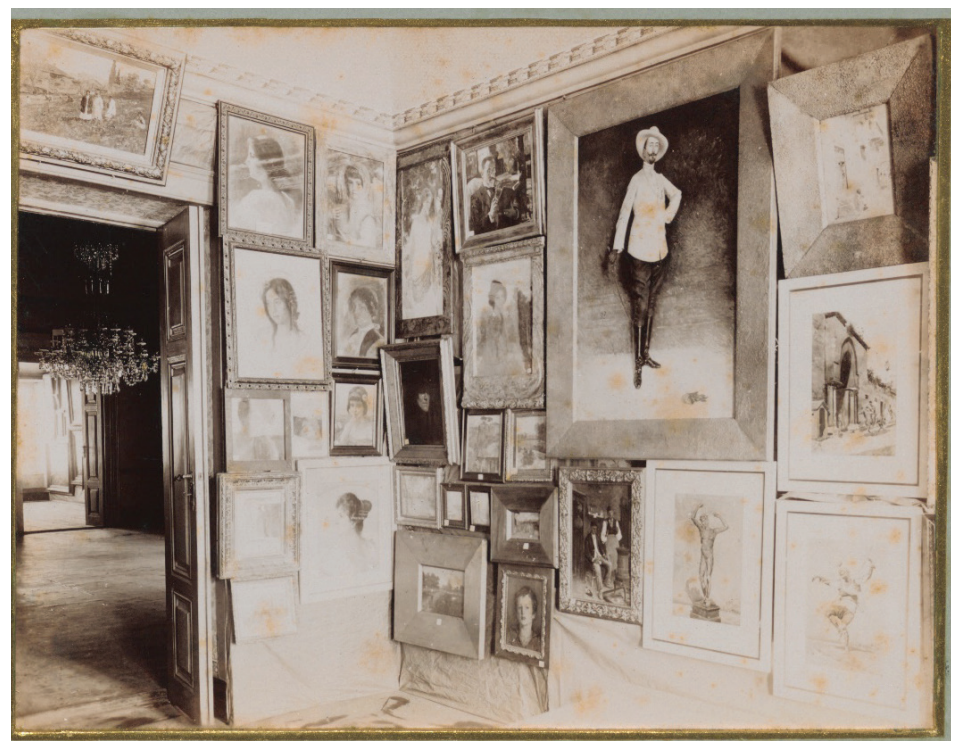

Görsel 1: 1902

Salonundan bir görünüm. Ortada yer alan tablo Georges Lemare'a ait "Eskrim Hocas1" isimli tablodur. Görselde Lemare'in tablosunun hemen solundaki iki tablonun Thalia Floras'a ait "Doktor F'nin Portresi" ile "Mavi Prenses" isimli eserler olduğu, daha altta görülen koyu renkli eserin ise "Matmazel Th'nin portresi" isimli eser olduğu tespit edilmiştir. İ̈̈ Nadir Eserler Kütüphanesi Y1ldız Albümleri 90528/9.

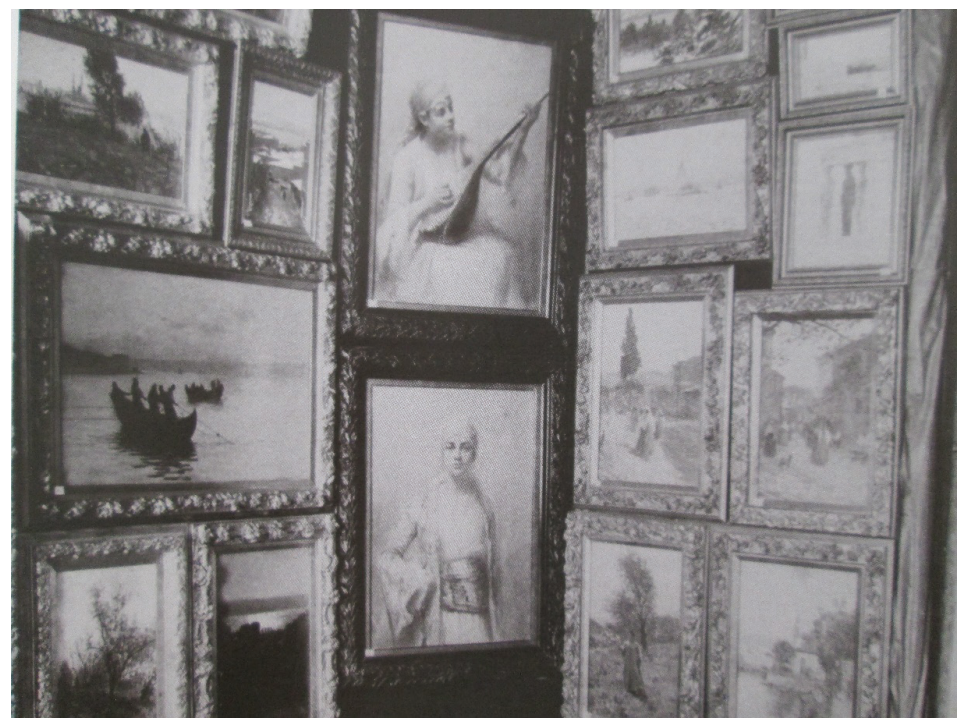

Görsel 2: Zonaro'nun "Saz Çalan kız" ve "Doğu kostümlü kız" isimli tabloları, 1902 Salonundan, İÜ Nadir Eserler Kütüphanesi Y1ldız Albümleri 90528/6. 


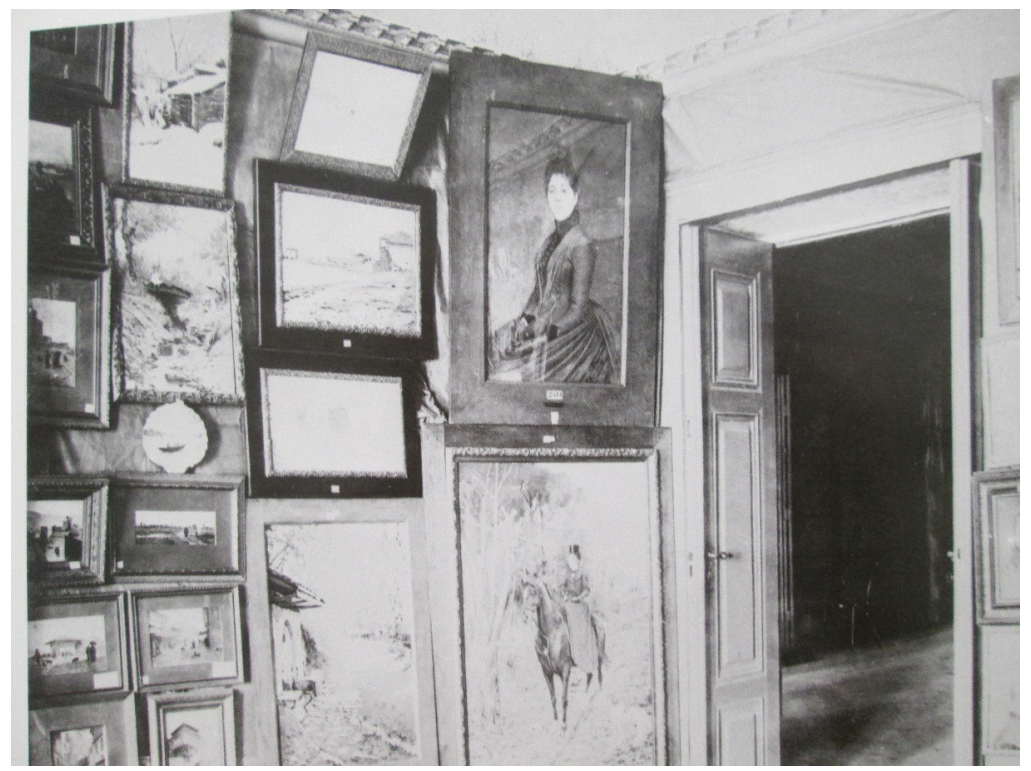

Görsel 3: 1902 Salonu'nda Halil Paşa'ya ait "Madame X" Tablosu ve altta “Amazon" isimli Bayan Patrick'in at üzerinde portresi, İÜ Nadir Eserler Kütüphanesi Yıldız Albümleri 90527/7.

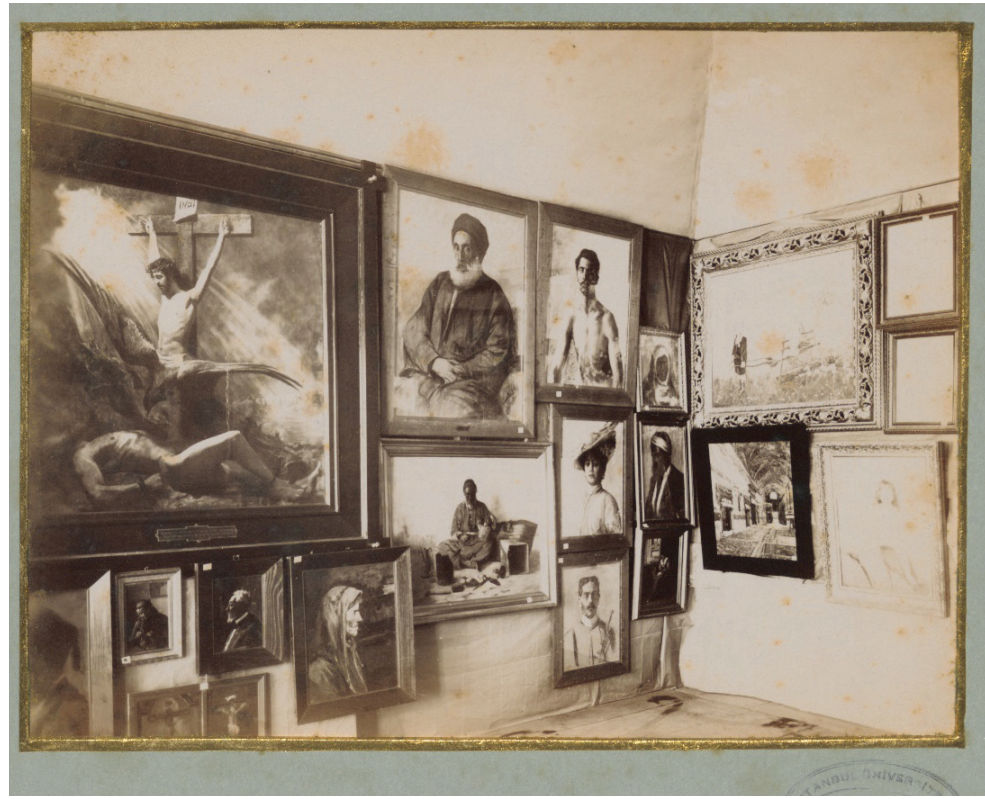

Görsel 4: 1902 Salonu'nda Vasmagidis’e ait “İnsanlığın iki büyük martiri” isimli tablo sol baştadır. Ahmed Rıfat'ın "Etüt” isimli üst kısmı çıplak gösterilmiş figürü ise sağ başa yakındır. İÜ Nadir Eserler Kütüphanesi Yıldız Albümleri 90528/14. 


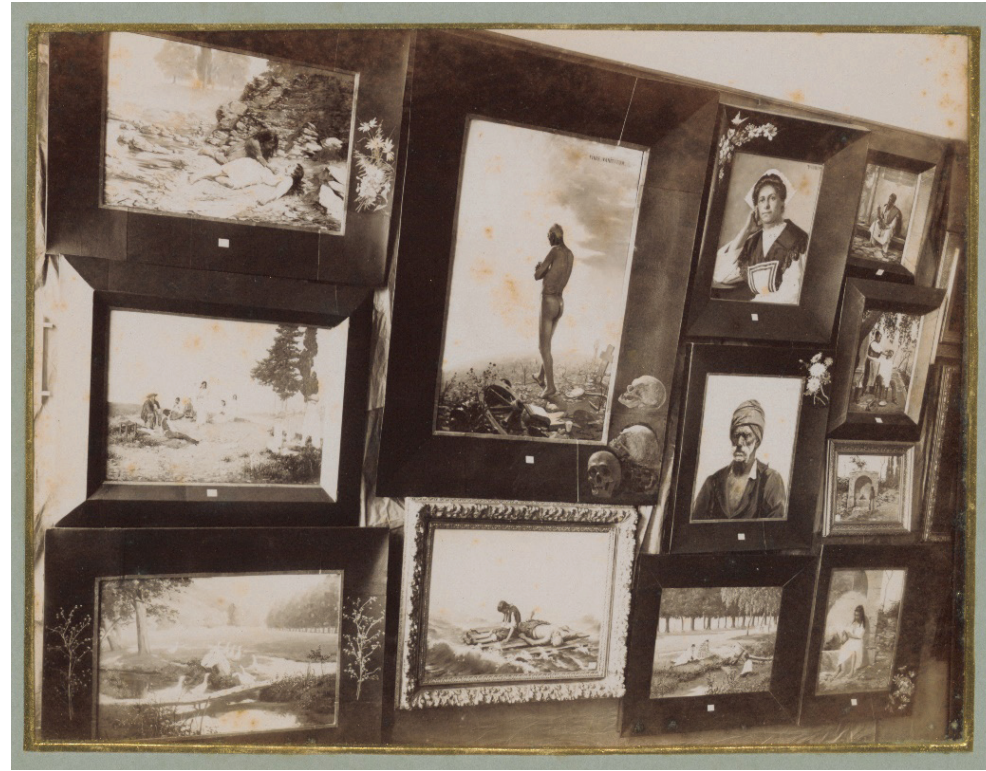

Görsel 5: 1902 Salonu'nda Warnia Zarzecki'nin "Mutlak Son” isimli tablosu üstte ortada görülmekle beraber bu duvar üzerindeki tüm eserler sanatçıya aittir. İÜ Nadir Eserler Kütüphanesi Y1ldız Albümleri 90528/11.

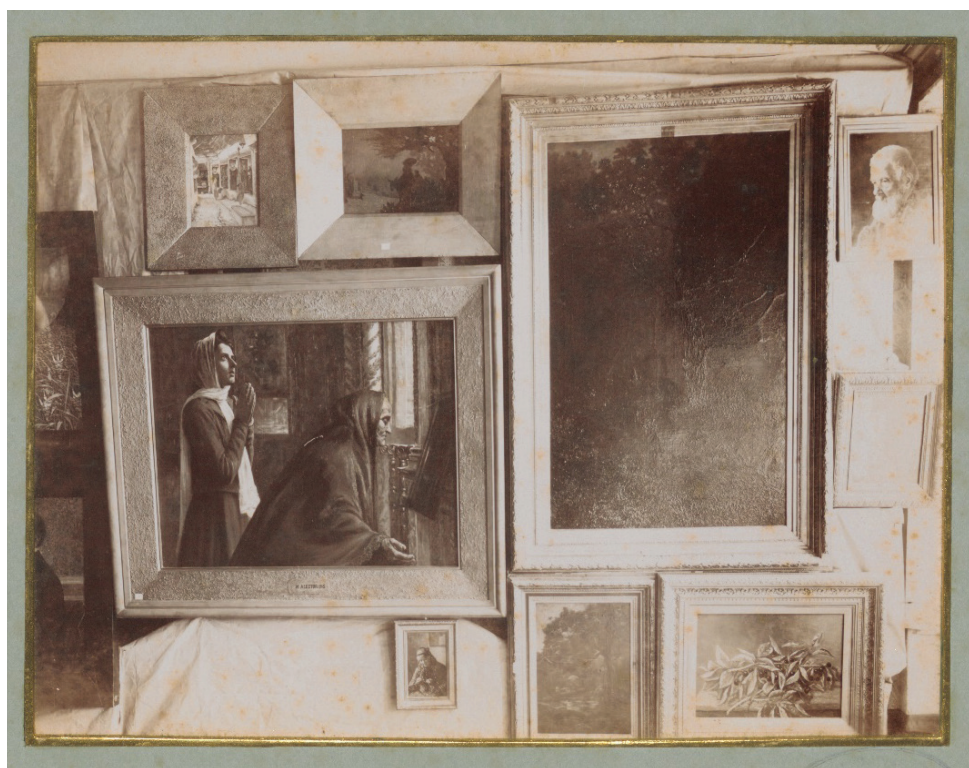

Görsel 6: 1902 Salonu'nda Alectoridis'in “Geçmiş ve gelecek için dua” isimli tablosu solda görülmektedir. İÜ Nadir Eserler Kütüphanesi Yıldız Albümleri 90528/16. 


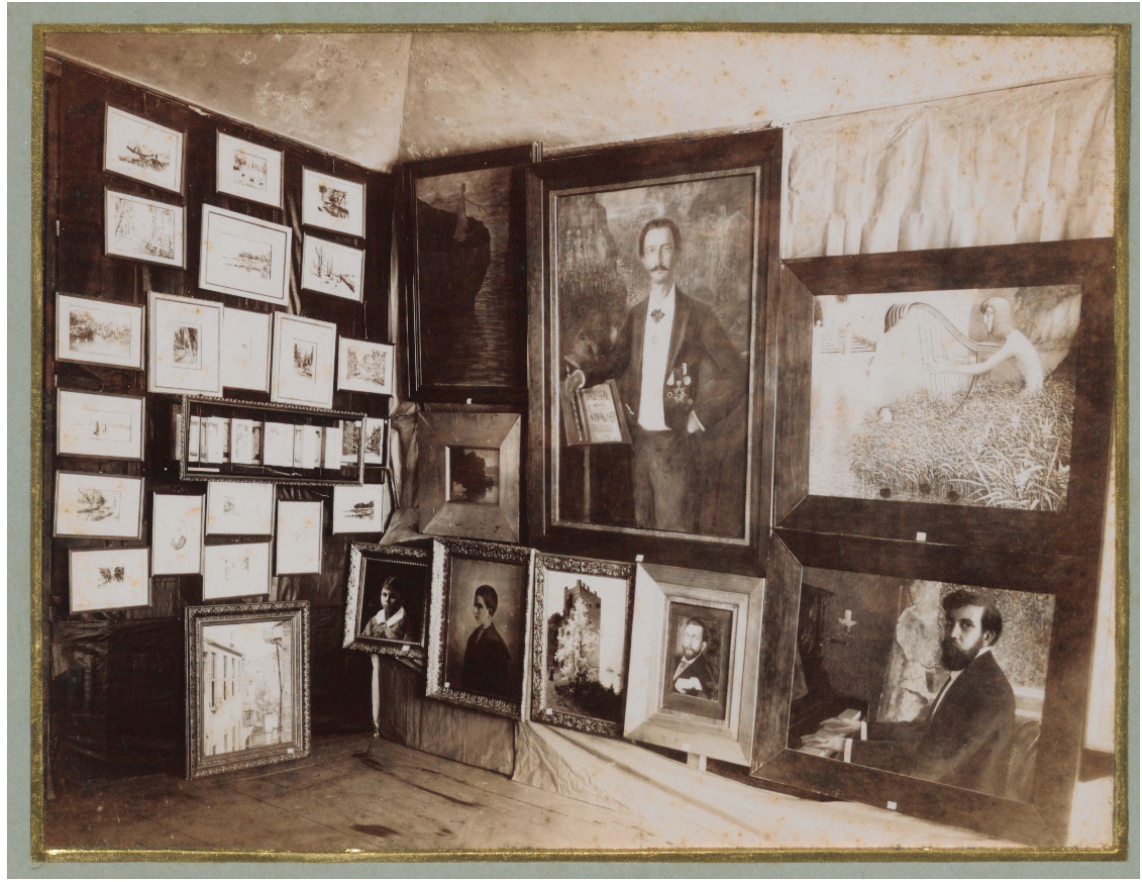

Görsel 7: 1902 Salonu'nda Paul Giese'e ait "Paul Lange portresi” ortada yeralırken, "Durgun göl" isimli tablosu sağ üstte görülmektedir. İÜ Nadir Eserler Kütüphanesi Yıldız Albümleri 90528/17.

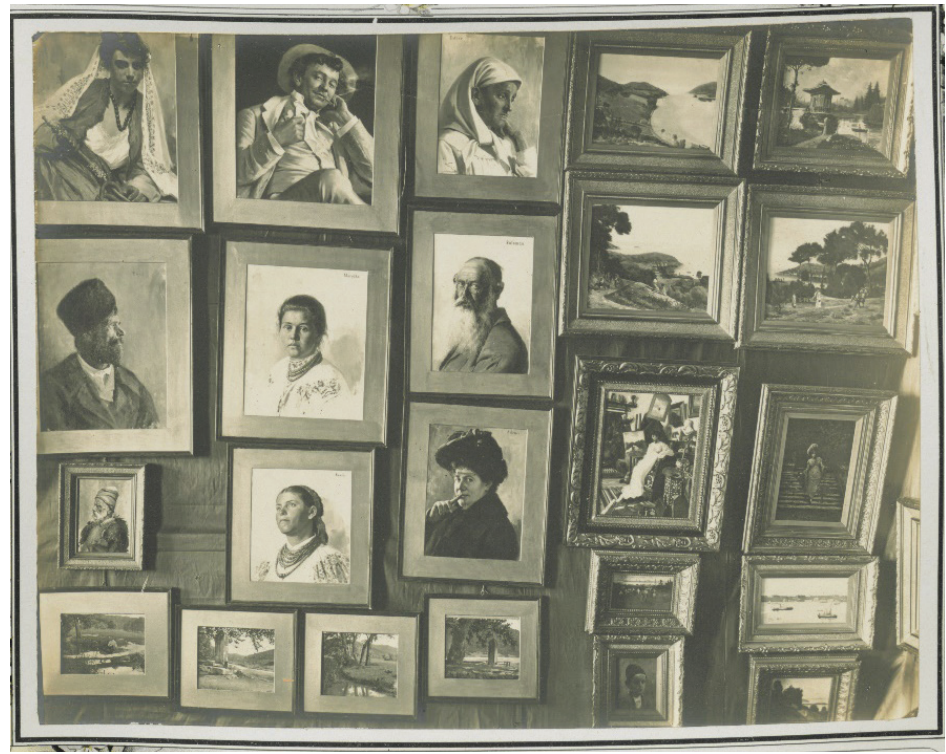

Görsel 8: 1903

Salonu'nda Ömer Adil Bey'in "Resimhanede" isimli eseri yukarıdan aşağıya doğru sağdan ikinci sıranın üçüncü tablosudur. Hemen bir solundaki portre ise Warnia Zarzecki'nin "Sükut" isimli portre çalışmasıdır. Görseldeki diğer portreler de (üzerlerinde de yazılı olduğu üzere Yvonne, Esther, Solomon, Marylka ve Kasia) Warnia'ya aittir. İÜ Nadir Eserler Kütüphanesi Yıldız Albümleri 90527/10. 


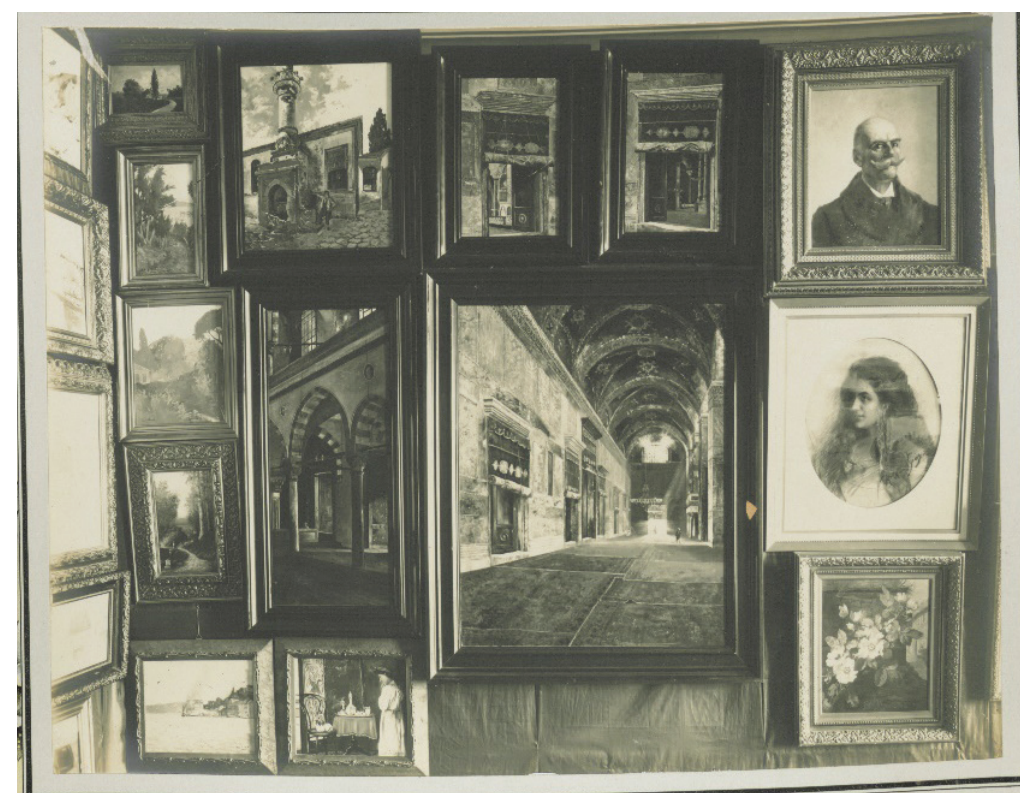

Görsel 9: 1903 Salonu'nda Şevket Bey’in “Ayasofya Camii içi” isimli tablosu merkezde yeralmaktadır. İÜ Nadir Eserler Kütüphanesi Yıldız Albümleri 90527/6.

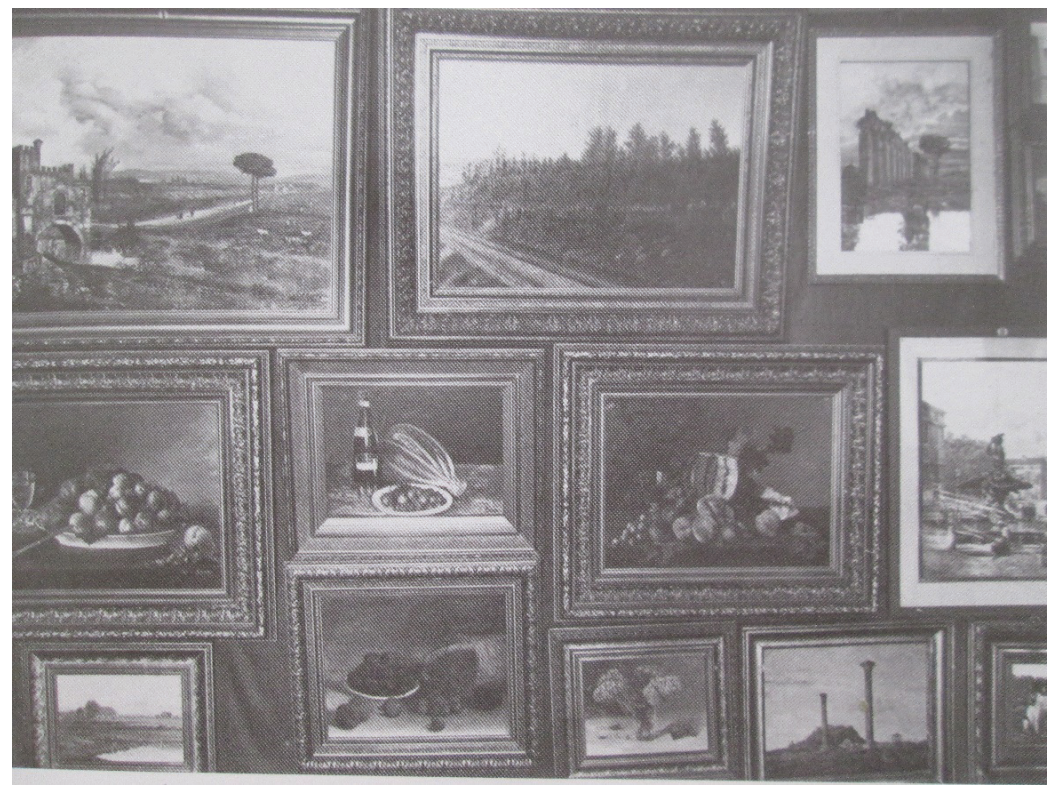

Görsel 10: Görselin orta kısmında bir şişe, marul ve tabakta meyvelerden oluşan "Meyve" isimli kompozisyon Ohannes Miasser'e aittir. 1903 Salonu'ndan bir görünüm. İÜ Nadir Eserler Kütüphanesi Y1ldız Albümleri 90527/11. 
Ege Üniversitesi, Edebiyat Fakültesi Sanat Tarihi Dergisi ISSN $1300-5707$ Cilt: 30, Sayı: 1 Nisan 2021
Ege University, Faculty of Letters Journal of Art History e-ISSN 2636-8064 Volume: 30, Issue: 1 April 2021

\section{İternet Sayfası (Aclk Erisim) | Internet Page (Open Access) \\ DergiPark \\ https://dergipark.org.tr/std}

Sanat Tarihi Dergisi hakemli, bilimsel bir dergidir; Nisan ve Ekim aylarında olmak üzere yılda iki kez yayınlanır.

Lournal of Art History is a peer-reviewed, scholarly, periodical journal published biannually, in April and October. 